\title{
CONFIDENTIALITY AND PRIVILEGE IN MEDIATION: CONCEPTS IN NEED OF BETTER REGULATION AND EXPLANATION
}

\author{
BOBETTE WOLSKI*
}

This article compares the regulatory framework (consisting of common law, agreements to mediate and legislation) governing the allied concepts of confidentiality and without prejudice privilege as they apply to the mediation of non-family law civil disputes in Queensland, New South Wales and Victoria. The analysis demonstrates that there is: lack of uniformity in regulation between, and within various jurisdictions; inconsistencies and conflict between multiple sources of regulation; illogical gaps in the framework; and fragmented and inaccessible explanations where accessibility refers to the ability of mediation participants to find and understand relevant provisions. These features of the regulatory system explain, in large part, why mediation providers often fail to give the parties clear and comprehensive explanations about these important mediation concepts. The article concludes by highlighting some of the issues around which reform efforts need to be focused if the regulatory system, and access to relevant information, is to be improved.

\section{INTRODUCTION}

Although confidentiality has been described as the 'sine qua non of mediation', ${ }^{1}$ courts and other mediation providers rarely give the parties a clear, accurate and comprehensive explanation of the concept of confidentiality, nor of the allied concept of without prejudice privilege, as these concepts pertain to mediation. The following are typical examples of the explanations given by

\footnotetext{
* BA, LLB, LLM (Dispute Resolution), PhD (ADR Ethics) (Bond), Associate Professor of Law, Bond University, Australia.

1 John K Arthur, 'Confidentiality and Privilege in Mediation' (2015) 2(5) Australian Alternative Dispute Resolution Law Bulletin 91, 91 (emphasis in original). Confidentiality has been described as the '[hallmark] of mediation', an essential element of mediation, and as 'one of the most crucial components of the mediation process': see T Noble Foster and Selden Prentice, 'The Promise of Confidentiality in Mediation: Practitioners' Perceptions' [2009] (1) Journal of Dispute Resolution 163, 164; Susan Oberman, 'Confidentiality in Mediation: An Application of the Right to Privacy' (2012) 27(3) Ohio State Journal on Dispute Resolution 539, 635; Joseph Lipps, 'The Path toward a Federal Mediation Privilege: Approaches toward Creating Consistency for a Mediation Privilege in Federal Courts' (2010) 4 American Journal of Mediation 55, 55.
} 
mediation providers, such as courts, about the status of communications made in mediation:

In contrast to court proceedings, which are open to the public, the mediation process is private and confidential. Anything said or produced in evidence at a mediation session cannot be used in a later hearing, except in exceptional circumstances. ${ }^{2}$

Mediation is conducted 'without prejudice', meaning nothing you say at mediation can be used in evidence in a later trial without your consent. Without prejudice discussions enable you to talk about your concerns openly and freely. You can propose any ideas that might settle the case. ${ }^{3}$

Records are not kept of discussions in mediation which allows for honesty and meaningful conversation that leads to resolution. Mediators do not communicate with anyone in the Court about what occurs or is said at a mediation. ${ }^{4}$

These explanations are taken from provider websites. As is evident from these quotations, the parties may be told that mediation is confidential or that it is conducted on a without prejudice basis. Sometimes, as in at least one of the examples given above, the issues of confidentiality and without prejudice privilege are conflated. While the issues are connected and may converge at some point (as discussed later in the article), confidentiality and privilege are separate concepts. ${ }^{5}$ More often than not, mediation communications are both confidential and privileged and as such, both concepts need to be explained to the parties. It is also evident from the above quotations that the protection afforded to mediation communications is sometimes overstated. ${ }^{6}$ There are circumstances in which the

2 'Mediation', Supreme Court of New South Wales (Web Page)

$<\mathrm{http}$ //www.supremecourt.justice.nsw.gov.au/Pages/SCO2_practiceprocedure/sco2_mediationinthesc/sc o2_mediationinthesc.asp $>$. In addition to appearing to conflate confidentiality and privilege, this explanation refers to material produced in mediation as 'evidence'. Mediation is not a process concerned with 'proof' of facts and nothing said or done in mediation is evidence. The 'exceptional circumstances' in which mediation communications might be admitted into evidence in a hearing before a court are not identified.

3 Information given about mediation on the website for Queensland Courts: 'Mediation', Queensland Courts (Web Page) <http://www.courts.qld.gov.au/going-to-court/alternative-dispute-

resolution/mediation $>$. There is no mention of 'confidentiality'. There is also no information given about possible exceptions or limitations to these principles.

4 Information given about the benefits of judicial mediation on the website for the Supreme Court of Victoria: 'Benefits of Mediation', Supreme Court of Victoria (Web Page)

$<$ https://www.supremecourt.vic.gov.au/law-and-practice/mediation/benefits-of-mediation>. A host of unanswered questions is raised by this information. For example, can mediators talk about the mediation to other third parties, apart from persons 'in the Court'? Are there circumstances in which mediators can reveal what was said or done in mediation? Do the parties owe a duty of confidentiality to each other? The fact that records are not kept will not by itself encourage honesty and candour for it will not stop the participants from talking to others about what was said or done at the mediation. Although the court website has a separate section dealing with ' $[\mathrm{w}]$ hat $[\mathrm{h}]$ appens at a [m]ediation', there is no mention made of confidentiality or privilege: 'What Happens at a Mediation', Supreme Court of Victoria (Web Page) $<$ https:/www.supremecourt.vic.gov.au/law-and-practice/mediation/what-happens-at-a-mediation>.

5 Recently commentators have stressed the fact that confidentiality and privilege are separate and distinct concepts, but they note that the concepts are often confused. See, eg, Gregory Firestone and Sharon Press, 'Privadentiality: Developing a Coherent Framework for Establishing Communication Protections in Family and Child Protection Dispute Resolution Methods' (2020) 58(1) Family Court Review 9, 11; Judge Joe Harman, 'The Protection of Confidentiality in Australian Family Law' (2020) 58(1) Family Court Review 126, 127.

6 Many parties consider confidentiality and privacy as two of mediation's most advantageous features. Yet as Boulle observes, while confidentiality is 'depicted as a defining feature' of the mediation process, 
duty of confidentiality does not apply and there are circumstances in which communications are not protected by privilege. These circumstances should not be glossed over with phrases like 'except in exceptional circumstances'. Further explanations about the concepts of confidentiality and the without prejudice privilege may be provided in agreements to mediate, in the case of private mediations, and also in legislation, but this information is often not accessible to the parties, where accessibility refers to the parties' ability to find and understand the relevant provisions. Another opportunity for clarification of these concepts arises in the mediator's opening statement, ${ }^{7}$ but many mediators will simply tell the parties that mediation communications are confidential, or made without prejudice, 'to the extent provided by the law'. All of these explanations are inadequate. ${ }^{8}$ In all, despite the importance of the principles of confidentiality and the without prejudice privilege to the integrity of the mediation process, ${ }^{9}$ it is questionable whether the parties know what the terms 'confidential' and 'without prejudice' mean, when they apply, and just as importantly, when they do not apply. ${ }^{10}$

'confidentiality and privacy are not the unqualified attributes frequently suggested': Laurence Boulle, Mediation: Principles, Process, Practice (LexisNexis Butterworths, $3^{\text {rd }}$ ed, 2011) 669, 670. Agapiou and Clark claim that there is a gap between the theory behind confidentiality in mediation and the reality in which the privacy of mediation 'may be rendered far more porous in practice' and 'simply an illusion': Andrew Agapiou and Bryan Clark, 'The Practical Significance of Confidentiality in Mediation' (2018) 37(1) Civil Justice Quarterly 74, 74, 76; while Bartlet observes that '[p]romises made during mediation regarding confidentiality may be far less watertight than parties to the mediation, or even the mediators themselves, may assume': Michael Bartlet, 'Mediation Secrets “in the Shadow of the Law"' (2015) 34(1) Civil Justice Quarterly 112, 112. See also Lipps (n 1) 55.

7 The mediation session proper usually begins with an introductory statement by the mediator during which he or she explains the mediator's role, the process involved, and the behavioural guidelines to be followed by the parties.

8 Boulle and Field observe that 'a statement that mediation is confidential unless disclosure is "required by law" is accurate, but ultimately not adequate or helpful on its own': Laurence Boulle and Rachael Field, Mediation in Australia (LexisNexis Butterworths, 2018) 341. See also Oberman, who asserts that 'mediators commonly make broad statements claiming that everything in mediation is confidential': Oberman (n 1) 542. In her view, such an '[o]versimplification of the offer of confidentiality fails to support self-determination of the parties in neglecting to give legal information that is necessary to make informed choices. Informed consent in mediation, as in medicine, is the basis for self-determination' (citations omitted). Foster and Prentice also note that it is common practice for mediators and counsel to describe mediation as confidential and privileged without any further explanation of what those terms mean, a practice that they believe is inadequate: Foster and Prentice (n 1) 171-2. See also Omer Shapira, A Theory of Mediators' Ethics: Foundations, Rationale, and Application (Cambridge University Press, 2016) 272.

9 National Alternative Dispute Resolution Advisory Council, Maintaining and Enhancing the Integrity of ADR Processes: From Principles to Practice Through People (Report, February 2011) 51 [3.8.3], 57 [4.1] ('Maintaining and Enhancing the Integrity of ADR Processes Report'). The National Alternative Dispute Resolution Advisory Council ('NADRAC') was established in 1995 to advise the Federal Attorney-General, and federal courts and tribunals about matters pertaining to alternative dispute resolution at the federal level. It was closed in 2013. However, NADRAC's publications are still highly regarded.

10 Tetunic and Firestone argue that mediators should explain these matters 'in an understandable manner' at the beginning of mediation so that the parties can make informed decisions. 'To do anything less could lead to an abuse of the process and undermine public confidence in mediation': Fran Tetunic and Gregory Firestone, 'Confidentiality and Privilege for Family and Child Protection Mediation: A Roadmap for Navigating the Innovation, Inconsistency and Confusion’ (2020) 58(1) Family Court Review 46, 61. 
To be fair to mediation providers, these concepts are not easy ones to explain ${ }^{11}$ in large part because of the following problems with the current regulatory system: ${ }^{12}$

1. Lack of uniformity: There is little uniformity in the way the concepts are regulated in Australia. The regulatory framework is a hodgepodge of common law principles; ${ }^{13}$ contractual provisions (in the case of privately arranged mediations); and legislation and rules of court. ${ }^{14}$ There are differences between: agreements to mediate issued by mediation

11 There is only so much information that can be accommodated in an opening statement. Even if mediators explained these concepts adequately in their opening statements, arguably, it is by then too late as the process has already commenced. Dewdney observes that one of the difficulties of attempting to explain the phrase " "so far as the law allows" is how to avoid giving parties so much information that they become confused': Micheline Dewdney, 'The Partial Loss of Voluntariness and Confidentiality in Mediation' (2009) 20(1) Australasian Dispute Resolution Journal 17, 18. Writing of the situation in the United States ('US'), Lipps commented that the mediator's opening statement promising confidentiality 'is wrought with a complex legal analysis where federal courts have contradicted one another', removing consistency and predictability with respect to the concept of confidentiality in mediation: Lipps (n 1) 55 .

12 The word 'regulatory' is used in a broad sense to encompass the body of law and principles which govern mediation practice and procedure, drawing on the definition in the Concise Oxford English Dictionary ( $11^{\text {th }}$ rev ed, 2008) 'regulate' (adj, def 2).

13 In this article, the phrase 'common law' refers to law made by judges in the exercise of both common law and equitable jurisdiction.

14 Rules of court comprise just one component of the law involved in taking a civil matter to court. If a civil dispute is litigated, it is necessary to take account of the following.

(a) Substantive law, which is the law being enforced (such as the law of contracts and equity).

(b) Procedural law, which is the law which governs the conduct of proceedings before a court, tribunal or quasi-judicial body. There are four sources of procedural law: civil procedure legislation in each jurisdiction (such as the Civil Proceedings Act 2011 (Qld)); legislation which establishes a particular court, its composition, administration and statutory powers (such as the Supreme Court Acts in various States and Territories); delegated legislation, that is, the rules of court devised by rules committees, which are made up of judicial officers and representatives of the government and the legal profession (such as the Uniform Civil Procedure Rules 1999 (Qld) ('UCPR')); and practice notes and directions made by the court pursuant to its inherent jurisdiction. See generally Stephen Colbran et al, Civil Procedure: Commentary and Materials (LexisNexis Butterworths, $7^{\text {th }}$ ed, 2019) 7-8. In Queensland and New South Wales, uniform Rules of Court have been adopted. They are uniform in that the one set of rules applies to proceedings conducted in the Magistrates' Court (or the Local Court in New South Wales), the District Court and the Supreme Court (see the UCPR 1999 (Q1d) r 3 and the Uniform Civil Procedure Rules 2005 (NSW) sch 1 reg 1.5, which includes a number of other courts and tribunals as well). In Victoria, there remains a separate set of rules for each court making up the judicial hierarchy. See discussion below $\mathrm{n}$ 115 (dealing with legislation and rules of court relevant to mediation referrals in the Magistrates' and County courts in Victoria); n 166 (dealing with legislation and rules of court relevant to the without prejudice privilege in the Magistrates' and County courts in Victoria).

(c) Evidence law, which regulates matters such as the competence and compellability of witnesses; provides rules as to admissibility of evidence, as well as exclusionary rules (such as sections 131(1) and 131(2) respectively of the Evidence Act 1995 (NSW)). Uniformity in evidence law has been achieved in New South Wales, Victoria and at the federal level: see discussion below n 20.

The sometimes-complicated interaction of these sources of law is evident in cases such as Woollahra Municipal Council v Secure Parking Pty Ltd [No 2] [2015] NSWSC 452 where the court had to consider various sections of the Civil Procedure Act 2005 (NSW), the Supreme Court Act 1970 (NSW), the Evidence Act 1995 (NSW), and the Uniform Civil Procedure Rules 2005 (NSW). 
institutions; agreements to mediate and legislation; and legislative arrangements in various jurisdictions. ${ }^{15}$

2. Inconsistent and conflicting provisions: Many mediations are subject to more than one source of regulation and there are often inconsistencies and conflict between relevant provisions. The principles for resolving conflict between different sources of regulation are not always clear.

3. Gaps: There are significant and illogical gaps in the regulatory framework.

4. Fragmented, inaccessible explanations: Explanations, such as they are, are split into multiple sources and they are usually written in the language of the law. This might be satisfactory for lawyers; it is not satisfactory for the many self-represented litigants (and potential litigants) who seek to use the civil justice system and who are, in many cases, compelled to attend mediation. ${ }^{16}$

There have been calls for reform of this area of mediation law and practice. ${ }^{17}$ However, to date, reform efforts have been slow.

The aim of this article is to explain the concepts of confidentiality and the without prejudice privilege as these concepts apply to communications made in mediation, and to substantiate the four claims made above about the current regulatory system. In so doing, the article demonstrates why reform is necessary. The article proceeds by way of an examination and comparison of the regulatory framework governing the mediation of non-family law civil disputes in

15 Other commentators have noted that the law in Australia in this regard is 'a rather unruly patchwork': Justice PA Bergin, 'The Global Trend in Mediation; Confidentiality; and Mediation in Complex Commercial Disputes: An Australian Perspective' (Conference Paper, Mediation Conference, 20 March 2014) 8. Justice Bergin further notes that '[ $t$ ] here is no single or uniform source of law governing the confidentiality of mediation in Australia': at 7. See also Boulle (n 6) 672.

16 It seems likely that the number of self-represented litigants has only increased in recent times. See E Richardson, T Sourdin and N Wallace, Self-Represented Litigants: Gathering Useful Information (Final Report, June 2012). Despite problems in gathering and reporting information, this report found that based on a literature review 'in all Commonwealth courts and tribunals', the proportion of self-represented litigants ranged from $17-93 \%$, 'reportedly greater than in previous decades': at viii. The only source of information for these potential litigants is likely to be court sites.

17 See, eg, Joe Harman, 'An Imperfect Protection: Attitudes of Family Dispute Resolution Practitioners to Confidentiality’ (2017) 29(1) Bond Law Review 39, 40 and references cited therein; Joe Harman, 'Confidentiality in Family Dispute Resolution and Family Counselling: Recent Cases and Why They Matter' (2011) 17(3) Journal of Family Studies 204 ('Confidentiality in Family Dispute Resolution'); Donna Cooper, 'Inconsistencies in and the Inadequacies of the Family Counselling and FDR Confidentiality and Admissibility Provisions: The Need for Reform' (2014) 4(4) Family Law Review 213; Dominik Leimgruber, 'Confidentiality, Public Interest and the Mediator's Ethical Dilemma' (2013) 24(3) Australasian Dispute Resolution Journal 187, 191-2; Tom Altobelli and Diana Bryant, 'Has Confidentiality in Family Dispute Resolution Reached Its Use By Date?' (Conference Paper, Seen and Heard: Children and the Courts Conference, 7-8 February 2015); Anthony Nolan and Michael O'Brien, 'Confidentiality in Mediations: A Work in Progress' (Conference Paper, Victorian Bar Alternative Dispute Resolution Committee, 12 May 2010) [7], [53]. See generally recommendations by National Alternative Dispute Resolution Advisory Council, Maintaining and Enhancing the Integrity of ADR Processes Report (n 9) 55-6 [3.9]. More recently, see Agapiou and Clark (n 6) 90; and the articles appearing in a special issue of the Family Court Review, including: Firestone and Press (n 5); Tetunic and Firestone (n 10); Harman, 'The Protection of Confidentiality in Australian Family Law' (n 5). However, see the view expressed by the New South Wales Law Reform Commission in Report No 146, discussed below $\mathrm{n} 191$. 
Queensland, New South Wales and Victoria. ${ }^{18}$ Mediators come from a variety of professional backgrounds and they may be subject to specific regulation by virtue of their profession. ${ }^{19}$ This article examines the law as it applies to all mediators, irrespective of their profession of origin.

The article is in five parts. Part II helps set the scene by defining crucial terms and by explaining how mediation might come about between parties in dispute. The sources, and scope of application, of the obligations of confidentiality in mediation are examined in Part III. Part IV looks at the sources, and scope of application, of the without prejudice privilege. In Parts III and IV, the interrelationship of various sources of regulation are examined. This includes a discussion of the impact of section 131 of the Uniform Evidence Acts ('the UEAs') in New South Wales and Victoria. ${ }^{20}$ The article concludes in Part V by highlighting some of the issues around which reform efforts need to be focused if the regulatory system, and access to relevant information, is to be improved.

Before proceeding to examine the obligations of confidentiality that arise in mediation, there are three pivotal terms that appear in the quotations at the beginning of the article which require a brief introductory explanation. These are essential terms that need to be explained to the parties. The terms are privacy, confidentiality and 'without prejudice privilege'. The terms are explained below. Currently these terms are not defined in any of the regulatory systems examined in this article. By way of background, it is also necessary to consider how mediation might come about, for this helps to explain why some mediations are subject to more than one source of regulation.

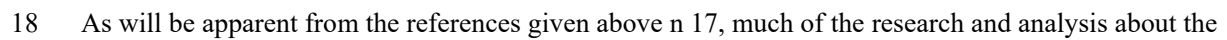
issues of confidentiality and privilege in mediation concern the regulation of these concepts as they pertain to family law. Less attention has been brought to bear on the application of these concepts to nonfamily law civil disputes. This article concerns both private and court-referred mediations of civil disputes. As concerns court-connected matters, it is not possible to examine every statutory scheme dealing with mediation. In this article, the examination of court-connected mediations focuses on those mediations ordered by the Magistrates', District and Supreme Courts in Queensland, and equivalent in New South Wales, and by the Supreme Court in Victoria. For an overview of legislation imposing confidentiality obligations on mediation participants, see National Alternative Dispute Resolution Advisory Council, Maintaining and Enhancing the Integrity of ADR Processes Report (n 9) 48-9 [3.6], apps 3.2, 4.1, 4.2.

19 For instance, lawyer mediators remain subject to relevant standards of conduct issued by their professional associations, including eg, an obligation to the court and the administration of justice. The obligations unique to lawyer mediators are not dealt with in this article. See generally, Bobette Wolski, 'Ethical Duties Owed by Lawyer Mediators: Suggestions for Improving the NMAS Practice Standards' (2017) 26(3) Journal of Judicial Administration 184. As for legal representatives for the parties, they are also bound by their professional conduct rules which may impact the obligation of confidence owed to their clients: see below n 28.

20 Uniform evidence legislation was passed in New South Wales and Victoria, and also by the Commonwealth of Australia, based on the Model Uniform Evidence Bill 2007 (Cth) as endorsed by the then Standing Committee of Attorneys-General in 2007, an initiative to achieve uniformity in the evidence legislation in Australia. See Evidence Act 1995 (NSW), Evidence Act 2008 (Vic), and Evidence Act 1995 (Cth) ('the UEAs'). Queensland did not adopt the Model Bill. The Evidence Act 1977 (Qld) has no terms regulating mediation and no section equivalent to or dealing with the subject matter of $U E A \mathrm{~s}$ 131. 


\section{PRELIMINARY MATTERS}

\section{A Terminology}

\section{Privacy}

The process of mediation generally takes place in a private forum to which members of the public do not have access. ${ }^{21}$ Usually only the immediate parties to the dispute attend the mediation, together with the mediator. ${ }^{22}$ The parties may have support persons such as lawyers also present. The proceedings are not recorded and minimal notes, if any, are made and retained by mediators. It is the private setting in which mediation takes place that makes it possible for mediation communications - which may be oral, written, or by conduct - to be cloaked in confidentiality.

\section{Confidentiality}

The words 'confidential' and 'confidentiality' are defined in the Oxford English Dictionary in terms of entrusting one's secrets to another. ${ }^{23}$ The word 'secrets' is not a helpful one to use in a mediation environment where candour is encouraged. Confidentiality may better be explained in terms of a duty or obligation owed by a person to refrain from disclosing statements made, and information provided, at or in connection with a 'mediation' to anyone other than the person who provided the information in the first place. ${ }^{24}$ It is important that the term 'mediation' be defined broadly. ${ }^{25}$ There are nearly always some limitations and exceptions to a duty of confidentiality. These are explored later in the article.

In mediation, there are at least two dimensions to confidentiality, and sometimes even three dimensions, corresponding to the central relationships that may co-exist in mediation. These are: confidentiality as between the parties, and as between the parties and the mediator with respect to communications made in joint sessions, ie, those sessions in which the mediator and all the parties are involved ${ }^{26}$ confidentiality of communications made between the mediator and a party in separate sessions, ie, those meetings held between the mediator and a party

21 In stark contrast, litigation takes place in a public forum (usually the court) and the proceedings form part of the public record. See Boulle (n 6) 673.

22 The parties and the mediator may not be in the same physical location. They may be communicating through telephone or video conferencing facilities.

23 Pocket Oxford Dictionary of Current English (5 $\left.5^{\text {th }} \mathrm{ed}, 1969\right)$ 'confidential'.

24 As will become evident later in the article, this is not a comprehensive definition, but it is sufficient for introductory purposes. For a variety of definitions which distinguish confidentiality and privilege in mediation, see Foster and Prentice (n 1) 164; Bartlet (n 6) 114; Harman, 'The Protection of Confidentiality in Australian Family Law' (n 5) 127; Lipps (n 1) 56.

25 The definition provided in the agreement to mediate issued by the Resolution Institute provides a useful example, stating that "The Mediation" shall comprise all steps taken to attempt to resolve the Dispute by mediation whether prior or subsequent to the execution of this agreement': Resolution Institute, 'Mediation Agreement' (Standard Agreement) cl $1<\mathrm{https} / /$ www.resolution.institute/resources/disputeresolution-clauses $>$. See below nn 71-5 and accompanying text.

26 Alexander refers to this dimension of confidentiality as insider/outsider confidentiality: Nadja Alexander, International and Comparative Mediation: Legal Perspectives (Wolters Kluwer, 2009) 249. 
in the absence of the other party; ${ }^{27}$ and, when a party is legally represented, confidentiality as between a lawyer and client. ${ }^{28}$ This article deals principally with the first two dimensions of confidentiality.

\section{Privilege}

If parties to a dispute commence litigation, they may be compelled to disclose certain 'documents' to each other under the civil procedure rules that exist in all jurisdictions. ${ }^{29}$ If a matter proceeds to a trial or hearing before a court (or other judicial body), documents and other information (such as the content of oral statements made by the parties to each other) might be admitted into evidence even though a party objects to admission of the material. ${ }^{30}$ However, some communications are protected from compulsory disclosure to an opponent and from compulsory admission into evidence in a hearing by operation of the concept of 'privilege'. At least four privileges are recognised under the common law. ${ }^{31}$ The without prejudice privilege, which has been codified in some jurisdictions, ${ }^{32}$ is the most relevant to mediation. ${ }^{33}$ It protects communications including admissions, concessions and offers to settle made by a party in a genuine attempt to resolve a

27 Ibid. Some mediations are conducted entirely by separate sessions. These mediations are commonly referred to as shuttle mediations.

28 When other helping professionals are involved eg, counsellors, they may bring additional dimensions of confidentiality to a mediation. For ease of reference, this article refers only to legal representatives and not to the part played by other support persons. Lawyers owe their clients a duty of confidence. The duty has long been recognised at common law and in equity. The duty has also been codified in the professional conduct rules: see, for example, Australian Solicitors Conduct Rules 2012 (Q1d) r 9; Legal Profession Uniform Conduct (Barristers) Rules 2015 (NSW) rr 114-18; Legal Profession Uniform Law Australian Solicitors' Conduct Rules 2015 (Vic) r 9. This aspect of confidentiality continues in mediation although it is not the mediator's function, nor the responsibility of the mediation provider if different from the mediator, to explain it to the client. The parameters of the lawyer's obligation of confidentiality owed to a client should be explained by the lawyer. However, in the author's experience, clients sometimes get this aspect of confidentiality mixed up with that of confidentiality of information revealed to the mediator, so it is as well for mediators to appraise themselves of the scope of lawyer/client confidentiality and in an appropriate case, to distinguish it from the duties of confidentiality arising as a direct result of the mediation.

29 The civil procedure rules in a particular jurisdiction may compel a party to litigation to provide to the other party or parties copies of documents in a party's possession or control that are directly relevant to an allegation in issue. For example, in Queensland, see UCPR 1999 (Q1d) r 211. The duty does not apply to documents to which there is a valid claim to privilege: at $\mathrm{r} 212(1)(\mathrm{a})$. The term 'document' is defined broadly: see, eg, the definition in the Acts Interpretation Act 1954 (Qld) sch 1. In some jurisdictions, a party must obtain an order for discovery from the court: see eg, Uniform Civil Procedure Rules 2005 (NSW) regs 5.3, 21.2.

30 See, eg, civil procedure rules by virtue of which a party may obtain a Notice to Produce (for a document held by a party) or a subpoena (for a document held by a non-party): UCPR 1999 (Q1d) rr 227 and 414 respectively.

31 These are: client legal privilege (or legal professional privilege), the privilege against self-incrimination, public interest privilege and the without prejudice privilege. See discussion by Andrew Hemming and Tania Penovic, Civil Procedure in Australia (LexisNexis Butterworths, 2015) 409-33.

32 In New South Wales and Victoria see Evidence Act 1995 (Cth) s 131.

33 The without prejudice privilege applies to communications made in mediation: AWA Ltd v Daniels (1992) 7 ACSR 463. See also the English cases of Farm Assist Limited (in liq) v Secretary of State for the Environment, Food and Rural Affairs [No 2] [2009] EWHC 1102 (TCC) [44] (Ramsey J) ('Farm Assist') discussed below n 89, and discussion therein of Brown v Rice [2007] EWHC 625 (Ch), [37] (Isaacs (QC)). 
dispute. Information which is protected by privilege is generally considered to be inadmissible as evidence in court proceedings. However, as with confidentiality, there are limits to the scope of privilege and circumstances in which otherwise privileged information might be admitted into evidence even though one or more mediation participants may object to its admission.

The rationale for recognising a duty of confidentiality in mediation, and for protecting certain information revealed in mediation by the concept of privilege, is discussed further in Parts III and IV respectively.

\section{B Mediations Subject to Multiple Sources of Regulation}

The exact scope of application of the duty of confidentiality, and of the protection of privilege, relating to mediation communications depends on the source/s to which the principles can be traced. The discussions in Parts III and IV examine first, the position at common law (and under the terms of an agreement to mediate) and second, the provisions of a number of legislative schemes. However, common law, contractual obligations and legislation cannot be considered in complete isolation from one another because a particular mediation might be regulated by more than one source. This might occur in circumstances such as the following:

1. Mediation might take place by agreement of the parties to the dispute, in which case, it is often referred to as private mediation as distinct from court-ordered or court-referred mediation. The agreement to mediate and general common law principles will govern the concepts of confidentiality and privilege in these circumstances. If the parties commence or continue litigation ${ }^{34}$ in New South Wales or Victoria and the matter proceeds to trial, the terms of the UEA in those jurisdictions must be taken into account. ${ }^{35}$ If there is a conflict between the terms of an agreement to mediate and legislation, the legislative provisions will prevail to the extent of any inconsistency. ${ }^{36}$ Common law principles will only be excluded in the case of a clear conflict with legislation. ${ }^{37}$

2. If litigation is commenced, ${ }^{38}$ the court may refer a dispute to mediation pursuant to specific legislation governing the conduct of civil proceedings in the relevant jurisdiction. Such legislation includes the Civil Proceedings Act 2011 (Qld), the Civil Procedure Act 2005 (NSW) and the Civil Procedure Act 2010 (Vic). If a matter proceeds to trial in New South

34 Court proceedings may be commenced or continued by a party because a settlement agreement was not reached in the mediation; or because, although a settlement agreement was reached, a party wishes to either a) enforce the agreement or b) challenge the validity of the agreement.

35 See explanations given above nn 14 and 20, of sources of law involved when a civil matter is litigated.

36 General legislation such as the UEAs will override conflicting terms of an agreement to mediate. See below n 104 for discussion of Silver Fox Co Pty Ltd v Lenard's Pty Ltd [No 3] (2004) 214 ALR 621 ('Silver Fox').

37 See Pihiga Pty Ltd v Roche (2011) 278 ALR 209 discussed below n 55, where the Federal Court of Australia discussed the principles for resolving conflict between the common law regulating the without prejudice privilege, an agreement to mediate and statute (namely the $U E A$ ).

38 See above nn 14 and 20 for an explanation of the law which may apply when litigation is commenced. 
Wales and Victoria, the terms of the UEA might also have to be considered. In this case, the specific legislation will prevail over general legislation such as the UEA if there is a conflict between relevant provisions. ${ }^{39}$ Specific legislation also trumps the terms of an agreement to mediate. ${ }^{40}$

Although the principles for resolving conflict between different sources of regulation are clear at an abstract level (as mentioned above), it will become evident in the discussion in the remainder of the article that resolution of conflicting terms is not always an easy matter and the task has, on a number of occasions, been referred to the court for a more nuanced approach.

The discussion below begins with an examination of the common law principles regulating the duties of confidentiality which arise in mediation.

\section{CONFIDENTIALITY IN MEDIATION}

As between the parties to a dispute and as between the parties and the mediator, things said and done in mediation are generally considered to be confidential as against the outside world. The rationale for recognising a duty of confidentiality in this context lies in public policy. It is in the public interest to conserve scarce court resources and to that end, to encourage the parties to a dispute to settle their differences by negotiation and compromise without the need for costly litigation. ${ }^{41}$ It is thought that the confidential setting of mediation will encourage the parties to be honest and open with each other for they may communicate without fear of public embarrassment or at the risk of exposure of sensitive information.

Separate sessions between the mediator and each of the parties in the absence of the other party are a unique feature of mediation. ${ }^{42}$ They are generally conducted on the basis that any communications made by a party to the mediator are confidential and that the mediator will not reveal those communications to the other party or to anyone else without the consent of the first mentioned party. ${ }^{43}$

39 See Forsyth v Sinclair [No 2] (2010) VR 635, 638 [12] (Neave and Redlich JJA and Habersberger AJA) discussed below n 180; Azzi (Automobiles) Pty Ltd v Volvo Car Australia Pty Ltd (2007) 71 NSWLR 140, 145-6 [18] (Brereton J) ('Azzi') discussed below nn 178-9 and accompanying text.

40 The parties may still enter into an agreement to mediate following the making of a court order that they attend mediation: see, eg, Sharjade Pty Ltd $v$ RAAF (Landings) Ex-Servicemen Charitable Fund Pty Ltd [2008] NSWSC 1347 in which the parties entered into an agreement to mediate and a separate confidentiality agreement in respect of a mediation ordered by the court under the Civil Procedure Act 2005 (NSW). See also Cook v Taing [2014] VSC 428. Many mediators - even those mediating courtreferred matters - will also ask the parties and their advisers to agree to confidentiality during preliminary meetings and in the mediator's opening statement.

41 For discussion of public policy considerations behind the concept of confidentiality in mediation, see Boulle (n 6) 670-2. See also Fiona Crosbie, 'Aspects of Confidentiality in Mediation: A Matter of Balancing Competing Public Interests' (1995) 2(1) Commercial Dispute Resolution Journal 51; Judge Joe Harman, 'Mediation Confidentiality: Origins, Application and Exceptions and Practice Implications' (2017) 28(2) Australasian Dispute Resolution Journal 106, 109-10, 117-20; Leimgruber (n 17) 190. Boulle (n 6) 243.

43 The mediator will usually commit to this arrangement at the outset of mediation and reaffirm it at the time separate sessions are commenced. 
There are a number of reasons for this aspect of confidentiality. The mediator may want to encourage a party to raise additional concerns and previously undisclosed information - information that the party is not comfortable with sharing in joint sessions. In separate sessions mediators may also explore options for settlement with a party without that party fearing loss of face..$^{44}$

However, the duty of confidentiality owed by the participants in mediation, whether in regard to information shared in joint or separate sessions, is not absolute. There are circumstances in which a party or a mediator may disclose otherwise confidential information to a non-participant, including a court, without the consent of the parties or party who divulged the information in the first place. These circumstances are canvassed later in the article. The rationale for recognising limitations on, and exceptions to, the duty of confidentiality in mediation also lies in public policy - some disclosures made in mediation should be brought to the attention of relevant authorities such as law enforcement or child welfare agencies. More generally, some matters are more appropriately dealt with in a public forum such as a court, for parties do not have an unfettered right to determine matters in private and on a confidential basis.

The exact scope of the duty of confidentiality owed in any particular case depends on the source/s to which the duty can be traced..$^{45}$ The discussion which follows examines first, the obligations of confidentiality which arise under the common law (including obligations which might be found in agreements to mediate); and second, statutory obligations of confidentiality.

\section{A Confidentiality Obligations Arising under the Common Law and Contract}

\section{The Position under the Common Law}

When the parties to a dispute enter into mediation by agreement, ${ }^{46}$ they and the mediator usually execute a written agreement to mediate whereby they agree that neither party nor the mediator will reveal communications made in mediation to a non-participant (ie, someone not present at the mediation, including a court), except in specified circumstances. In this case, the foundation of the duty of confidentiality is primarily the agreement to mediate ${ }^{47}$ and the scope of the duty depends on the terms of the contract, supplemented by general common law principles. ${ }^{48}$

44 Separate sessions might also be used to provide a safe zone for the expression of emotion or for the mediator to redress inappropriate behaviour.

45 For a general discussion of the possible sources of the obligation of confidentiality, see Arthur (n 1) 91. See also National Alternative Dispute Resolution Advisory Council, Maintaining and Enhancing the Integrity of ADR Processes Report (n 9) 44-9 [3.4]-[3.6]; Shapira (n 8) 272; Boulle and Field (n 8) 324 5; Bartlet (n 6) 114-19.

46 There is no legal requirement that an agreement to mediate be in writing although a written agreement might be easier to prove and to enforce.

47 Sometimes the parties and the mediator might enter into a stand-alone confidentiality agreement.

48 The contractual terms regulating confidentiality may be express or implied. According to NADRAC, '[c]ourts may be willing to imply confidentiality into contracts for mediation, if to do so would reflect the parties' intentions and implication of a confidentiality obligation is necessary to give business efficacy to a contract': National Alternative Dispute Resolution Advisory Council, Maintaining and Enhancing the 
A clearer picture of the way in which confidentiality is regulated in private mediations can be gained by looking at specific agreements to mediate. Two sample agreements will be discussed shortly. In neither example are lawyers for the parties actually parties to the agreement to mediate and as such, there is unlikely to be a contractually based duty of confidentiality owed by the lawyers to the opposing party or to the mediator. Nor are lawyers likely to stand in a fiduciary relationship with opposing parties or the mediator. However, a lawyer may owe an equitable obligation to the other party if the pre-requisites discussed below are met.

In some circumstances, the duty of confidentiality may be traced to equity. The classic formulation of the 'elements' required for recognition of a duty of confidentiality in equity comes from Gummow $\mathrm{J}$ in Smith Kline \& French Laboratories (Aust) Ltd v Secretary, Department of Community Services and Health ('Smith Kline'), ${ }^{49}$ where his Honour stated that

an equitable obligation of confidence has four elements: (i) the plaintiff must be able to identify with specificity, and not merely in global terms, that which is said to be the information in question, and must be able to show that; (ii) the information has the necessary quality of confidentiality (and is not, for example, common or public knowledge); (iii) the information was received by the defendant in such circumstances as to import an obligation of confidence, and (iv) there is actual or threatened misuse of that information, without the consent of the plaintiff. ${ }^{50}$

The case of Smith Kline did not concern a mediation although its principles remain relevant to the discussion. Of more interest for present purposes is the decision of the New South Wales Court of Appeal in Worth Recycling Pty Ltd v Waste Recycling \& Processing Pty Ltd ('Worth Recycling') ${ }^{51}$ where Hodgson JA (with whom Spigelman CJ and Campbell JA agreed) cited with approval the fourelement test set out above in Smith Kline. ${ }^{52}$ Hodgson JA went on to hold that if the elements articulated in Smith Kline are satisfied, the solicitor for one party in mediation may owe an obligation of confidence to the other party. ${ }^{53}$ Despite this judgment, the law concerning recognition of an obligation of confidentiality in mediation based in equity has not been fleshed out well by the courts. ${ }^{54}$

Integrity of ADR Processes Report (n 9) 45 [3.4.3]. As far as the author is aware, the scope of an implied duty of confidentiality as between the mediator and the parties has not been described by the courts. In the context of the lawyer/client relationship, Dal Pont observes that there has been little attempt to describe the scope of the implied duty and it is safe to assume that the position is the same with the mediator/parties relationship: GE Dal Pont, Lawyers' Professional Responsibility (Lawbook, $5^{\text {th }}$ ed, 2013) $334-5$.

49 (1990) 22 FCR 73, 87 ('Smith Kline').

50 Ibid.

51 [2009] NSWCA 354 ('Worth Recycling').

52 Ibid [24] (Spigelman J agreeing at [1], Campbell JA agreeing at [50]). Hodgson JA also agreed with Gummow J that it is not necessary "that the breach must inflict or be likely to inflict "detriment": Smith Kline (1990) 22 FCR 73, 87, 112 (Gummow J), quoted in Worth Recycling [2009] NSWCA 354, [24][25] (Hodgson JA).

53 This decision turned on the wording of the agreement to mediate and the circumstances of the mediation. The agreement, which was signed only by the parties and the mediator, contained reasonably comprehensive provisions on confidentiality. While the agreement was not signed by the lawyer, the lawyer had been present at the mediation and was familiar with the terms of the agreement to mediate: Worth Recycling [2009] NSWCA 354, [26]-[30] (Hodgson JA).

54 See discussion by National Alternative Dispute Resolution Advisory Council, Maintaining and Enhancing the Integrity of ADR Processes Report (n 9) 47-8 [3.5.2]. According to NADRAC, the law as 


\section{(a) Exceptions and Limitations to Confidentiality of Mediation Communications under the Common Law}

There are a number of common law-based exceptions to the principle of confidentiality which must be taken into account, for the common law is not necessarily ousted by agreement of the parties. ${ }^{55}$ While the following is not an exhaustive list, it covers some of the circumstances most likely to arise. They include: ${ }^{56}$

1. Consent: As a general principle, confidentiality can be waived with the consent of the person/s whom it was intended to protect.

2. Enforcing and/or challenging the validity of a mediated settlement agreement ('MSA'): Evidence may be admitted at a hearing before a court to prove that an agreement was reached in mediation and to establish the terms of the agreement. ${ }^{57}$ When a party alleges that they entered into an agreement as a result of misconduct by the other party, ${ }^{58}$ the mediator, ${ }^{59}$ or the party's own legal adviser, ${ }^{60}$ evidence of mediation communications may be admitted in proceedings to set aside or rectify the agreement and in proceedings based on the alleged misconduct. Examples of misconduct

regards claims based in equity is unsettled. For a discussion of the circumstances in which a lawyer for one party may owe an obligation of confidence to an opponent in mediation based in equity, see Anton Trichardt, 'Duty of Confidentiality to Opposing Party Resulting from Settlement Negotiations' (2019) 33(2) (June-August) Commercial Law Quarterly 3.

55 See Pihiga Pty Ltd v Roche (2011) 278 ALR 209 concerning proceedings in the Federal Court of Australia in which the applicants sought an order to set aside or rescind a settlement deed entered into following private mediation on the ground of alleged misrepresentation by the respondents. Lander J, discussing the terms of an agreement to mediate and its relationship with the common law, commented ' $[\mathrm{t}$ ] hat protection [under an agreement to mediate] is in my opinion no greater than that given by the common law and if the without prejudice privilege is lost because of the exceptions at common law it cannot be maintained under the mediation agreement': at 227 [111]. In short, an agreement cannot enlarge the protection given at common law. In the circumstances of this case, the Court held that the protection of the without prejudice privilege was lost and that the applicants were entitled to adduce relevant evidence where they claimed that a concluded agreement had been reached 'in circumstances where they were misled': at 225 [97].

56 See Boulle (n 6) 691-700 for discussion of exceptions to confidentiality under the common law, including a discussion of relevant case law. See also Alan L Limbury, 'Should Mediation Be an Evidentiary “Black Hole”?' (2012) 35(3) University of New South Wales Law Journal 914, 919.

57 See Harrington v Lowe (1996) 190 CLR 311, 326 in which the High Court of Australia held that without prejudice material will be admissible in evidence if the issue is whether or not an agreement was reached as a result of negotiations [in a conciliation conference held under the Family Law Act 1975 (Cth)] and whether or not a party entered into 'an impugned agreement' as a result of 'misleading and deceptive conduct by another party'.

58 See ibid. See also the decision of the Federal Court of Australia in Pihiga Pty Ltd v Roche (2011) 278 ALR 209, discussed above n 55.

59 See Tapoohi v Lewenberg [No 2] [2003] VSC 410 ('Tapoohi').

60 See ibid; Studer v Boettcher [1998] NSWSC 524 in which a client sued his own lawyer for negligence, undue influence and misleading conduct during mediation. See the discussion by Boulle of the three court decisions he refers to as the 'Studer saga': Boulle (n 6) 299-300 (emphasis in original). 
include misleading and deceptive conduct, unconscionability, coercion and duress, and negligence. ${ }^{61}$

3. Offence or fraud: In the case of an allegation that an offence or fraud occurred during the mediation, evidence may be admitted in proceedings relating to the alleged offence or fraud. It may be that the information can also be disclosed to relevant officials, such as law enforcement agencies, but there is a lack of clarity on this issue.

While some of these exceptions are phrased in the language of admissibility of evidence, if evidence of particular communications is admitted into court proceedings, the communications are not confidential. It is at this point that the two principles, and exceptions to the principles, converge.

There is another important common law-based limitation on the scope of confidentiality (and also of privilege) afforded to communications made in mediation which potentially could arise in every mediation, even those that are court-referred. In the case of AWA Ltd v Daniels ${ }^{62}$ the solicitors for the plaintiff referred to the existence of certain documents at mediation. When mediation failed, the defendant's solicitors issued to the plaintiff notices to produce those documents at trial. ${ }^{63}$ The plaintiff's solicitors sought to have the notices to produce set aside. Rolfe J, who was not the trial judge, refused to set aside the notices. His Honour held that the notices to produce should be enforced because they did not seek to prove directly or indirectly statements made at the mediation:

They seek to prove, by admissible evidence, a fact to which reference was made at mediation not by reference to the statement but to the factual material which sourced the statement. A finding to the contrary would mean that irrespective of relevance to issues the statement at mediation made the factual material upon which it was based immune from subsequent consideration by the Court ...64

On appeal, Rogers CJ approved of Rolfe J's line of reasoning, and observed that 'as a matter of principle it would be entirely too easy to sterilise otherwise admissible, objective, evidence simply by saying something about it in the course of the mediation, even if the subject be irrelevant to the mediation discussion'. ${ }^{65}$

The Queensland Supreme Court relied on the decision of Rolfe J in the case of Williamson $v$ Schmidt ${ }^{66}$ where the plaintiff in the instant case was represented by

61 See Harrington v Lowe (1996) 190 CLR 311, 326; Pihiga Pty Ltd v Roche (2011) 278 ALR 209, discussed above n 55; Studer v Boettcher [1998] NSWSC 524; and Tapoohi [2003] VSC 410 where a party to a mediation alleged that former lawyers had breached their common law duty of care to the party; the mediator was joined by third party notice by the lawyers. In Tapoohi, although it concerned a private mediation, an agreement to mediate had not been signed by the parties. For discussion of Tapoohi, see Boulle (n 6) 731-7. See generally Boulle for discussion of relevant cases: at 693-6.

62 (1992) 7 ACSR 463.

63 A notice to produce is usually issued to a party to compel them to produce specified documents at trial. In AWA Ltd v Daniels (1992) 7 ACSR 463, the documents were discoverable in any event.

64 AWA Ltd v Daniels (Supreme Court of New South Wales, Rolfe J, 18 March 1992) 6, quoted by Young J in Lukies $v$ Ripley [No 2] (1994) 35 NSWLR 283, 288-9.

65 AWA Ltd v Daniels (1992) 7 ACSR 463, 468 (Rogers CJ). Conversely, parties may hold back from mentioning issues which are important to them if they fear that they will be precluded from raising those issue again in a subsequent trial if the mediation is unsuccessful. For a discussion of AWA Ltd v Daniels (1992) 7 ACSR 463, see Boulle (n 6) 677-8. 
lawyers who had acted for a different plaintiff against the same defendant in an earlier case which went to mediation. Adopting the approach of Rolfe $\mathrm{J}$ in $A W A$ Ltd $v$ Daniels, Lee J held

that the plaintiff in the District Court action is entitled to prove if it can by admissible evidence, subject to any without prejudice considerations, the existence of any fact or matter disclosed at the mediation proceedings, although the plaintiff cannot lead in evidence, in those later proceedings, anything done or said or any admission made at the mediation proceedings ${ }^{67}$

These two cases do not concern an exception to the principles of confidentiality and privilege. Rather they are authority for the proposition that the duty of confidentiality and the protection of privilege do not extend, and have never extended, to otherwise admissible evidence of the existence of objective facts. ${ }^{68} \mathrm{It}$ seems not to matter that a party only looked for the independent source to establish the fact or matter because they learned of the fact or matter in mediation. ${ }^{69}$

Unfortunately, this limitation on the scope of confidentiality (and privilege) in mediation is not mentioned on the provider websites from which the opening quotations are taken; in the agreements to mediate examined below; or in most legislative schemes that provide for mediation. ${ }^{70}$

In the next section, two agreements to mediate containing express terms dealing with confidentiality are examined.

\section{Confidentiality Provisions in Sample Agreements to Mediate}

There are a number of 'model' agreements to mediate available for use in private mediations. These have been issued by lawyers' professional associations and organisations such as the Resolution Institute ('RI'). ${ }^{71}$ While there are some common features in these standard-form agreements, there are also differences

67 Ibid 336 (Lee J).

68 See also the explanation of this concept in Your Guide to Dispute Resolution, prepared by NADRAC for the Commonwealth of Australia: National Alternative Dispute Resolution Advisory Council, 'Your Guide to Dispute Resolution' (Guide, 2012) < https:/www.ag.gov.au/sites/default/files/2020-

03/Your\%20Guide\%20to\%20Dispute\%20Resolution.pdf $>$. NADRAC suggests that it may be possible to bring ADR discussions to the court where 'the information is from ADR discussions and it is information that is available separately from and independently of the ADR process (that is, the information would be available even if there had not been an ADR process)': at 35 [4.5].

69 As Lee J noted in Williamson $v$ Schmidt [1998] 2 Qd R 317, 336: 'It would, in my opinion, be very difficult for any court at any stage to enter into a hearing as to when a party, or his solicitor who engaged in a mediation conference, first acquired knowledge, whether prior to the mediation, at the mediation, or subsequent thereto', although Rogers CJ took a different view in AWA Ltd v Daniels (1992) 7 ACSR 463, $467-8$. The court is always mindful of the need to avoid satellite litigation.

70 This particular limitation on the concepts of confidentiality and privilege could be explained to parties using explanations such as that given by National Alternative Dispute Resolution Advisory Council, 'Your Guide to Dispute Resolution' (n 68) and by examples such as the following: 'If, at mediation, party $\mathrm{X}$ admits they drove through a red light and collided with party $\mathrm{Y}$ 's car, party $\mathrm{Y}$ cannot use this statement in evidence at a subsequent trial of the matter, but they can prove that $\mathrm{X}$ ran the red light by eg dashcam footage, CCTV and witness accounts'.

71 Resolution Institute ('RI') is one of the major mediation institutions operating in Australia. It combines two organisations ie, Leading Edge Association of Dispute Resolvers ('LEADR') and Institute of Arbitrators and Mediators Australia ('IAMA'). 
between them. The agreement issued by the RI, and the agreement issued by the Law Society of New South Wales are examined below. ${ }^{72}$

\section{(a) General Provisions as to Confidentiality of Mediation Communications}

In relation to confidentiality generally, clause 19 of the agreement to mediate published by the RI provides:

The Parties and the Mediator will not unless required by law to do so, disclose to any person not present at the Mediation, nor use, any confidential information furnished during the Mediation unless such disclosure is to obtain professional advice or is to a person within that Party's legitimate field of intimacy, and the person to whom the disclosure is made is advised that the confidential information is confidential. ${ }^{73}$

By virtue of clause 1 of the RI agreement, 'The Mediation' comprises 'all steps taken to attempt to resolve the Dispute by mediation whether prior or subsequent to the execution of th[e] agreement' to mediate. ${ }^{74}$ As such, information revealed by a party during preliminary meetings with the mediator and during intake sessions, ${ }^{75}$ is also confidential even if these events occur before the agreement to mediate is executed. Confidentiality might also extend to activities which occur, and documents which come into existence, after the formal mediation meetings have ended, provided those activities can be considered steps taken in an attempt to resolve the dispute by mediation. It is not clear that an MSA will automatically be confidential by virtue of this provision but the parties may include a term to this effect in any agreement that they reach.

The RI agreement binds the mediator and the parties but not the parties' lawyers or other support persons.$^{76}$ However, the parties agree that they will have support persons execute an acknowledgement and undertaking as to confidentiality (as specified in schedule 3 of the RI agreement). ${ }^{77}$ A mediator may refuse to start or continue the mediation unless the required undertaking is given. The RI undertaking provides that support persons will keep confidential 'all information disclosed during the Mediation' unless they are 'compelled by law' to disclose the information or they do so "with the consent of the Party who disclosed the confidential information' ${ }^{78}$

Like the RI agreement, the agreement issued by the Law Society of New South Wales binds the mediator and the immediate parties to the dispute but no-one else.

72 These two agreements have been chosen because they are freely available online and because they offer useful points of comparison between an agreement provided by a general (and well-known) mediation institution and another promulgated by a lawyers' professional body. Resolution Institute (n 25) cl 19.

74 Ibid cl 1.

75 An intake session is usually conducted by the mediation provider before the mediation proper begins. It may consist of face to face or telephone meetings with each of the parties alone, and/or involve completion and submission of various forms. The purpose of intake is to obtain background information about the parties and the dispute and ultimately to assess the suitability of the dispute for mediation. Many mediators will also obtain a verbal commitment regarding confidentiality at the commencement of the mediation process and this arguably extends to the parties' lawyers: see Worth Recycling [2009] NSWCA 354, which tends to support this conclusion. Ibid sch 3 cl 2(a)-(b). 
There are three clauses that deal with confidentiality (and privilege). Under the heading 'Communication Between the Mediator and the Parties', clause 14 provides: 'Any information disclosed to a mediator in private is to be treated as confidential by the mediator unless the party making the disclosure states otherwise'. ${ }^{79}$ This clause is adequate to protect the confidentiality of communications made in separate sessions. There are problems if one attempts to apply the provision to communications made in joint sessions. For instance, in a joint session, Party A could make a statement to the mediator concerning Party B which Party B does not want repeated outside of mediation. Since Party B did not make the disclosure, Party B may be unable to prevent the mediator or Party A from repeating the communication elsewhere. Also, the confidentiality of partyto-party communications are not protected under this provision.

Under the heading 'Confidentiality of the Mediation', clause 15 provides as follows: 'The participants will not disclose to anyone not involved in the mediation any information or document given to them during the mediation unless that person has signed the prescribed Confidentiality Agreement in the form attached to this Agreement. ${ }^{80}$ The wider term 'the participants' in this clause (in contrast to the phrase 'the party' used in clause 14) is apparently intended to mean the parties and the mediator, although this is a matter which should be clarified. When read in conjunction with the attached confidentiality agreement, the idea is that neither the parties nor the mediator will discuss mediation communications with legal representatives and other support persons unless the latter have signed the confidentiality agreement.

The confidentiality of party-to-party mediation communications is not protected by clause 15 , nor by any other clause in this agreement. There is also no general provision protecting the confidentiality of communications made by mediators to the parties. ${ }^{81}$

There are other problems with the Law Society's precedent agreement, and with the attached confidentiality agreement. ${ }^{82}$ The term 'during the mediation' which appears throughout, is too narrow although there is an attempt to include 'a preliminary conference' as part of the mediation by virtue of clause 11. In this respect, the wider terms of the RI agreement are to be preferred. The definition of 'mediation' contained in agreements to mediate (and in legislation) is crucial for

79 Law Society of New South Wales, 'Agreement to Mediate' (Sample Agreement) cl 14.

80 Ibid cl 15. This provision is confusing. It appears that the term 'them' refers to the participants and that the phrase 'that person' refers to legal representatives and other support persons.

81 Despite clause 16 of the Law Society's agreement to mediate appearing under the heading 'Confidentiality of the Mediation', as the clause makes reference to '[privilege]', 'subpoena', 'evidence' and 'produc[ing]' documents 'in any proceedings in respect of the Dispute', it appears to go only to evidentiary matters ie, it is concerned with privilege: Law Society of New South Wales (n 79) cl 16. While it may prohibit admission of various communications into evidence, it does not prevent disclosure in the boarder context outside of the mediation and outside of court.

82 Of the two agreements examined here, only the RI agreement prohibits 'use' of confidential information: see Resolution Institute (n 25) $\mathrm{cl}$ 19, sch $3 \mathrm{cl}$ 2(c). Improper use of information furnished during a mediation is not examined in this article except in as much as it also involves a breach of the duty of confidentiality. Not only does it raise the issue of breach of confidentiality, it also raises an issue of conflict of interest for mediators which is outside the scope of the article. 
determining when the process, and the protection of confidentiality, begins and ends.

The 'Confidentiality Agreement for Observers or Support Persons' which is attached to the Law Society's agreement to mediate is notable for its lack of detail. ${ }^{83}$ It appears that clause 1 was designed to prevent disclosure of information revealed in joint sessions while clause 2 was intended to protect information gleaned in separate sessions. Under clause 1, disclosure can be made if 'required by law', a phrase which is not explained; under clause 2, disclosure can be made only with the express consent of the disclosing party.

\section{(b) Confidentiality of Communications Made in Separate Sessions}

The RI agreement to mediate makes explicit provision for confidentiality of communications made in separate sessions which may take place during mediation. The agreement provides that the mediator may meet with the parties together or separately ${ }^{84}$ and that information disclosed to a mediator by a party in confidence in a separate session need not be disclosed by the party and 'may not be disclosed by the Mediator to any other Party unless the Party by whom that information was disclosed consents to such disclosure' ${ }^{85}$ This is the only explicit exception to confidentiality. Although it is not made explicit in the agreement, it is likely that mediators can also make disclosures when 'required by law to do so', taking advantage of clause 19 (as mentioned above) although the precise meaning of this clause is uncertain. ${ }^{86}$

As discussed above, clause 14 of the agreement to mediate issued by the Law Society of New South Wales can be applied to communications made in separate meetings. Such communications are confidential 'unless the party making the disclosure states otherwise' ${ }^{87}$ There are no other exceptions stipulated.

\section{(c) Exceptions and Limitations to Confidentiality under Agreements to Mediate}

It is common for agreements to mediate to include some information about the circumstances in which a duty of confidentiality will not apply. However, the information in the agreements discussed here is sparse and there are some differences between the terms used in the agreements. The following circumstances are usually mentioned:

1. Consent: Agreements to mediate may differ in their provisions as to whose consent is required to enable disclosure of otherwise confidential information. The consent of the party who disclosed the information may be required, or the consent of all the parties may be necessary. ${ }^{88}$ In fact,

\footnotetext{
83 Law Society of New South Wales (n 79) 'Confidentiality Agreement for Observers or Support Persons'.

84 Resolution Institute (n 25) cl 17.

85 Ibid cl 18.

86 Ibid cl 19 (emphasis added).

87 Law Society of New South Wales (n 79) cl 14.

88 Neither agreement discussed here includes clear provisions regarding consent. The RI agreement itself does not include a consent provision in relation to information shared in joint sessions. Clause 20 of the RI agreement seems to be pitched at information revealed by a party in separate sessions: Resolution
} 
case law and commentary suggests that, where there is an express agreement as to confidentiality not only as between the parties, but also as between the parties and the mediator, the mediator's consent may also be required to waive confidentiality. ${ }^{89}$ That said, where the parties wish to call evidence from the mediator in subsequent court proceedings, the court may override the confidentiality provision and order that the mediator give evidence where the court considers that it is necessary in the interests of justice. ${ }^{90}$

2. Provision for discussion with third parties: The RI agreement foreshadows that a mediation participant might want to discuss the mediation with persons within their 'legitimate field of intimacy', such as, with their family or with anyone else who might be directly affected by the outcome of the mediation. ${ }^{91}$ It is practically impossible to prevent (or to regulate) these types of discussions anyway. Under the RI agreement, provision is also made to enable the parties to discuss mediation communications with lawyers and other relevant professionals..$^{92}$ While the agreement to mediate of the Law Society of New South Wales does not include express provisions to this effect, such 'outside' communications are possible as long as the attached confidentiality agreement has been completed by the support person involved.

3. Disclosure when required by law: The RI agreement provides that information can be revealed when disclosure is 'required by law'. ${ }^{93}$ For some reason, this exception is only specified in the Confidentiality Agreement rather than in the main agreement to mediate of the New South Wales Law Society. Where the expression is used in these agreements, its meaning is not explained.

4. Proceedings to enforce (and challenge) an MSA: Both agreements to mediate provide that an MSA may be enforced. ${ }^{94}$ The provisions of the Law Society agreement to mediate do not appear to allow for the

Institute (n 25) cl 20. The same uncertainty surrounds clause 14 of the NSW Law Society agreement to mediate: Law Society of New South Wales (n 79) cl 14.

89 Farm Assist [2009] EWHC 1102 (TCC), [43]-[44] (Ramsey J). In this case, a party sought an order to set aside the MSA on the basis of alleged economic duress. A witness summons was issued to the mediator. The proceedings before Ramsey $\mathrm{J}$ concerned an application to set aside the witness summons. His Honour held that although the mediator had 'an enforceable right to confidentiality', it was in the interests of justice that she gave evidence: at [52]-[53]. The application was dismissed. See also Limbury (n 56) 917; Bartlet (n 6) 116.

90 This is consistent with the general view that the protection of privilege exists for the benefit of the parties, not the mediator, and so can be waived by the parties. See Farm Assist [2009] EWHC 1102 (TCC), [29], [44] (Ramsey J), discussed above n 89. See also Limbury (n 56) 917.

91 Resolution Institute (n 25) cl 19.

92 Ibid. The 'Agreement to Mediate' of the Law Society of New South Wales does not include an express provision to this effect: see above $\mathrm{n} 79$. Ibid.

94 Resolution Institute (n 25) cl 24; Law Society of New South Wales (n 79) cl 22. Under the Society's agreement, the MSA must be expressed to be binding on all parties. 
possibility of a party challenging the validity of an MSA. ${ }^{95}$ The wording of clause 24 of the RI agreement is broader. It enables a party to bring proceedings for enforcement of any agreement reached in the mediation and in such proceedings to 'adduce evidence of and incidental to the settlement agreement including evidence from the Mediator' and any other mediation participant. ${ }^{96}$ Thus, should a party wish to resist enforcement of, and challenge, the validity of an MSA on the ground of, eg, unconscionability, they may be able to adduce evidence of questionable statements and/or conduct under this provision. This broader clause is to be preferred.

Neither the RI agreement nor the agreement to mediate of the Law Society of New South Wales contains a complete list of possible exceptions to confidentiality under the common law. However, cases and commentary make clear that common law exceptions such as those discussed earlier may still apply. ${ }^{97}$ But this information is unlikely to be accessible to the parties unless it is included in the agreement which they sign and is explained to them in easy to understand terms. As mentioned already, parties also need to know that the principle of confidentiality will not prevent them from proving, in subsequent judicial proceedings, a fact or matter mentioned in the mediation by otherwise admissible evidence.

If parties to a dispute commence or continue litigation, regard might also have to be had to specific legislation by which the courts are empowered to order parties to mediation, as well as to general legislation such as the UEA in New South Wales and Victoria. Legislative provisions impacting the issue of mediation confidentiality are discussed next.

\section{B Confidentiality Obligations Imposed by Legislation}

\section{Impact of General Legislation}

As mentioned above, if litigation is commenced or continues following an 'unsuccessful' mediation ${ }^{98}$ and the matter proceeds to trial, the issue of confidentiality of mediation communications may be impacted by general legislation such as the UEA which codifies the law of evidence in some jurisdictions. ${ }^{99}$ Section 131 of the UEA in New South Wales and Victoria is of particular significance. It codifies the common law without prejudice privilege.

95 See the narrow provisions of clauses 22-4 dealing with enforcement of MSAs in the New South Wales Law Society agreement to mediate: Law Society of New South Wales (n 79) cl 22-4.

96 Resolution Institute (n 25) cl 24(ii).

97 See above nn 55-66 for discussion of relevant cases and accompanying commentary. See also Cook $v$ Taing [2014] VSC 428, a case of a court ordered mediation where the parties entered into an agreement to mediate. The Practice Court of the Supreme Court of Victoria indicated that it would apply common law principles to determine if the parties are bound by an agreement purportedly reached at mediation, and to determine if there has been a meeting of the minds: at [88]-[95] (Elliott J). See generally Boulle and Field (n 8) 324.

98 Even a mediation which does not result in a final agreement may be beneficial leading to clarification of issues, agreement on some issues and agreement on the process to be followed after mediation.

99 See above nn 14 and 20 for discussion of sources of procedural and evidentiary law when a matter is litigated. 
Section 131(1) provides that information from settlement negotiations conducted between parties, or between one or more of the parties and a third party, such as occurs in mediation, is not to be adduced in evidence. However, section 131(2) lists a series of circumstances in which section 131(1) does not apply and evidence of communications from a negotiation may be admitted into evidence. In effect, the section also provides for exceptions to confidentiality for, as was mentioned previously, if something is admitted into evidence, it is no longer confidential.

Some of the most important circumstances included in section 131(2) are: when the parties consent to admission of the evidence (the consent of all the persons in dispute is required); ${ }^{100}$ where the proceeding in which it is sought to adduce the evidence is a proceeding to enforce a settlement agreement or a proceeding 'in which the making of such an agreement is in issue' (as is the case if a party wishes to challenge the validity of an alleged agreement, eg, on the grounds of misleading and deceptive conduct or unconscionability); ${ }^{101}$ where the court is likely to be misled unless the evidence is admitted;102 and where "the communication was made, or the document was prepared, in furtherance of the commission of a fraud or an offence or the commission of an act that renders a person liable to a civil penalty'. ${ }^{103}$ This last mentioned exception to privilege is potentially very wide and could, for example, be relied upon by a party who alleges negligence on the part of the mediator or their legal adviser. These clauses will override conflicting terms of a confidentiality provision in an agreement to mediate. ${ }^{104}$

Where a dispute is referred to mediation by the court, it may be necessary to consider the interaction of general legislation and the specific legislation pursuant to which the referral order is made. The common law including the provisions of any agreement to mediate may continue to be relevant, as explained below.

$100 U E A$ s 131(2)(a). There are various other subsections dealing with implied consent. Regardless of what a particular agreement to mediate specifies about consent, evidence of what was said or done at a mediation will only be admitted into evidence on the basis of consent in New South Wales and Victoria, with 'the consent of "the persons in dispute", for UEA section 131(2)(a) prevails over inconsistent terms of any agreement.

101 Ibid s 131(2)(f).

102 Ibid s 131(2)(g)

103 Ibid s 131(2)(j).

104 See Silver Fox (2004) 214 ALR 621 where Mansfield J held that statutory provisions such as UEA s 131(2)(h) override the confidentiality clauses in an agreement to mediate. In this case, the parties took part in a private mediation pursuant to an agreement to mediate which provided for confidentiality of communications at mediation; and further provided, that any settlement proposal made in the course of the mediation would be 'privileged' and not tendered as evidence in any subsequent proceedings. The matter did not settle and eventually the applicant sought costs on an indemnity basis (a matter which is at the discretion of the court under section 43 of the Federal Court of Australia Act 1976 (Cth)). In support of the claim, the applicant sought to adduce two affidavits of their solicitors, one of which included details of the final proposals put by the applicants and by the respondents before mediation broke down. The applicant argued that receipt of the evidence of those communications was authorised by section 131(2)(h) of the Evidence Act 1995 (Cth), an argument that was accepted by Mansfield J: at [37]. The two affidavits were admitted into evidence. However, his Honour did not believe the offers provided 'a proper basis for departing from the normal rule as to costs': at [38]. The respondent's refusal to accept the applicant's offer was not unreasonable on the part of the respondent. 


\section{Specific Legislation Governing Court-Referred Mediations in Queensland, New South Wales and Victoria}

Increasingly, parties are referred to mediation under the terms of legislation with most courts and tribunals in Australia having the power to refer parties to mediation with or without their consent. ${ }^{105}$ In this section of the article, consideration is given to the legislative framework underlying court-referred mediations of non-family law civil disputes in Queensland, New South Wales and Victoria. ${ }^{106}$

Court-referred mediation in Queensland is governed by the Civil Proceedings Act 2011 (Qld) and the Uniform Civil Procedure Rules 1999 (Qld). ${ }^{107}$ Section 54(1) of the Civil Proceedings Act 2011 (Qld) provides that: 'An ADR convenor must not, without reasonable excuse, disclose information coming to the ADR convenor's knowledge during an ADR process' ${ }^{108}$ The legislation in Queensland makes it clear that an ADR process includes 'all the steps involved in an ADR process', including pre-mediation and post-mediation activities and joint and separate sessions. ${ }^{109}$

The circumstances in which a mediator has a reasonable excuse to disclose information under the Queensland scheme are discussed shortly. Perhaps the most notable difference between the contractual obligations of confidentiality discussed earlier and the legislative obligations created in Queensland is that the latter only bind the mediator. Mediators are prohibited from repeating mediation communications anywhere, both in and out of court. As for the parties and their lawyers, section 54 of the Civil Proceedings Act 2011 (Qld) is silent, but they may at least be prohibited from repeating mediation communications in court by section 53 of the Civil Proceedings Act 2011 (Qld) which deals with privilege (and is discussed in Part IV of the article). The parties' out-of-court disclosure of mediation communications is unregulated unless the parties have entered into an agreement to mediate. General common law principles may also continue to apply.

105 In Queensland, see Civil Proceedings Act 2011 (Qld) ss 43(3), 44; in New South Wales, see the Civil Procedure Act 2005 (NSW) ss 26(1), 27; in Victoria, see Civil Procedure Act 2010 (Vic) s 66. Most courts also have power to refer a matter to mediation as part of their case management duties. See, for example, in Queensland, the UCPR 1999 (Qld) r 367(1) which empowers the court to make 'any order or direction about the conduct of a proceeding it considers appropriate'.

106 Additional requirements and exceptions to confidentiality may be made in the case of specialised areas of mediation practice, with mediations conducted under the Family Law Act 1975 (Cth) ('FLA') providing the best example.

107 Civil Proceedings Act 2011 (Qld) pt 6 and UCPR 1999 (Qld) rr 319-33 which apply to the Magistrates', District and Supreme Courts of Queensland (see UCPR 1999 (Qld) r 3 as to application of the rules).

108 Civil Proceedings Act 2011 (Qld) s 54(1). By virtue of the Civil Proceedings Act 2011 (Qld) s 39(1), an ADR process is defined as 'a process of mediation or case appraisal'. A mediator is an ADR convenor.

109 Ibid s 39(2). This is important, as demonstrated by discussions in relation to mediation conducted under the FLA 1975 (Cth) with some commentators arguing that the FLA 1975 (Cth) has defined preliminary meetings and intake sessions out of the relevant definition, so that communications made in those stages of the mediation process are not protected by confidentiality. See, eg, Harman, 'Confidentiality in Family Dispute Resolution' (n 17) 205-6. Harman calls the exclusion of intake sessions from the protection afforded Family Dispute Resolution ('FDR') by virtue of section $10 \mathrm{H}$ of the FLA 1975 (Cth) '[p]erhaps the single greatest difficulty and threat to the confidentiality of FDR': at 206. 
In the case of any conflict between these various sources, the terms of the Civil Proceedings Act 2011 (Qld) will prevail.

Court-ordered mediation in New South Wales is governed by the Civil Procedure Act 2005 (NSW) and by the Uniform Civil Procedure Rules 2005 (NSW). ${ }^{110}$ Section 31 of the Civil Procedure Act 2005 (NSW) deals with confidentiality. In contrast to the Queensland scheme, the definitions of 'mediation' and 'mediation session' for the purpose of section 31 do not make it clear whether there is a duty of confidentiality with respect to pre- and postmediation activities and no mention is made of separate sessions. ${ }^{111}$ Section 31 of the Civil Procedure Act 2005 (NSW) provides that a mediator may disclose 'information obtained in connection with the administration or execution of this Part only in one or more' of specified and limited circumstances, as discussed further below. ${ }^{112}$ The terms of this section may be wide enough to cover communications revealed in joint and separate sessions.

Under the New South Wales scheme, like the one in Queensland, the duty of confidentiality applies only to mediators. They are prohibited from repeating communications made in mediation anywhere. The statutory scheme established by the Civil Procedure Act 2005 (NSW) is silent in relation to obligations of confidentiality owed by the parties and their lawyers. They may be prohibited from repeating mediation communications in court by virtue of section 30 of the same Act dealing with privilege. Section 131 of the UEA might also have to be taken into account if the matter proceeds to trial. Otherwise, as is the case in Queensland, the parties' out-of-court disclosure of mediation communications is unregulated unless the parties happen to have entered into an agreement to mediate. They may also be bound by general common law principles. In the case of any conflict between these sources, specific legislation will prevail over general legislation, ${ }^{113}$ which in turn will prevail over any agreement to mediate and any inconsistent common law principles.

The Civil Procedure Act 2010 (Vic), ${ }^{114}$ by virtue of which the court can refer parties to mediation, ${ }^{115}$ must be read in conjunction with the Supreme Court Act

110 Civil Procedure Act 2005 (NSW) pt 4 and Uniform Civil Procedure Rules 2005 (NSW) pt 20 div 1, which apply to the Local, District and Supreme Courts as well as other courts mentioned in column 1 of schedule 1 (see rule 1.5 as to application of the rules).

111 See Civil Procedure Act 2005 (NSW) s 25. Mediation is defined as 'a structured negotiation process in which the mediator, as a neutral and independent party, assists the parties to a dispute to achieve their own resolution of the dispute'. A mediation session is defined as 'a meeting arranged for the mediation of a matter'.

112 Ibid s 31.

113 Forsyth v Sinclair [No 2] (2010) 28 VR 365 discussed below n 180; Azzi (2007) 71 NSWLR 140 discussed below nn 178-9 and accompanying text.

114 With some exceptions, this legislation applies to all civil proceedings in Victoria.

115 See Civil Procedure Act 2010 (Vic) s 66. Referral to mediation may also take place, with or without the parties' consent, under the Magistrates' Court Act 1989 (Vic) s 108(1) and the Magistrates' Court General Civil Procedure Rules 2010 (Vic) rr 50.04, 50.06. Powers under these sections must be exercised '[s]ubject to and in accordance with the Rules or the Civil Procedure Act 2010': Magistrates' Court Act 1989 (Vic) s 108(1). In the County Court of Victoria, referral to mediation may also take place, with or without the parties' consent, under the County Court Act 1958 (Vic) s 47A and County Court Civil Procedure Rules 2018 (Vic) r 34A.21. Unlike Queensland and New South Wales, uniform rules have not been promulgated in Victoria. 
1986 (Vic) and the Supreme Court (General Civil Procedure) Rules 2015 (Vic) rule 50.07(1). The term 'mediation' is not defined in the Victorian legislative scheme. There is a definition of 'appropriate dispute resolution' in section 3 of the Civil Procedure Act 2010 (Vic) (and this definition is adopted by section 3 of the Supreme Court Act 1986 (Vic)). While the definition includes 'mediation', it does not define mediation and offers no guidance as to when mediation begins and ends for the purposes of determining confidentiality issues or issues related to the without prejudice privilege. Nor is it clear that communications in both joint and separate sessions are protected. The Supreme Court Act 1986 (Vic) section 24A provides that: ${ }^{116}$

Where the Court refers a proceeding or any part of a proceeding to mediation, other than judicial resolution conference, unless all the parties who attend the mediation otherwise agree in writing, no evidence shall be admitted at the hearing of the proceeding of anything said or done by any person at the mediation.

Section 24A directly concerns the (in)admissibility of mediation communications into evidence. However, it seems that the section was also intended to provide for confidentiality of mediation communications, as evident from a similarly worded provision in the Magistrates' Court General Civil Procedure Rules 2010 (Vic) which appears under the heading 'confidentiality'. ${ }^{117}$ To a limited extent, section 24A does double duty providing for privilege and indirectly for confidentiality. In contrast, the legislative schemes in Queensland and New South Wales make separate provision for confidentiality and for privilege.

Section 24A is unlike the provisions operating in Queensland and New South Wales in other important respects. It closes the gap identified above in the legislative schemes in Queensland and New South Wales for it applies to all mediation participants, not just mediators. However, it opens other gaps for it is narrow in two respects. First, the section only prevents mediation participants from repeating what was said or done in mediation in court - it does not prevent participants including the mediator from repeating mediation communications elsewhere, out of court, to third parties. This is in contrast to the specific legislative provisions in Queensland and New South Wales which, though they only apply to mediators, prohibit the information from being repeated anywhere. Second, section $24 \mathrm{~A}$ only prevents mediation participants from repeating mediation communications in the same proceedings (or in respect of the same subject matter) as that in which the mediation was ordered by the court. ${ }^{118}$ It will apply when the parties do not settle in court-ordered mediation and the matter continues to trial. This aspect of section 24A is discussed again later in the article. The terms of the legislation in Queensland and New South Wales are not so restricted.

As is the case with the specific legislation operating in New South Wales, section 24A prevails over inconsistent provisions of general legislation such as the

116 An almost identical provision is made in the relevant legislation governing the Magistrates' and County courts in Victoria. See provisions mentioned above n 115.

117 Magistrates' Court General Civil Procedure Rules 2010 (Vic) r 50.11.

118 See Simply Irresistible Pty Ltd v Couper [2010] VSC 505, [11]-[13] discussed below n 153, a case which highlights this narrow aspect of the operation of section $24 \mathrm{~A}$. 
UEA 2008 (Vic), ${ }^{119}$ and over inconsistent provisions of any agreement to mediate ${ }^{120}$ and the common law. However, because the scope of section $24 \mathrm{~A}$ is relatively narrow, the instances of conflict will be fewer than those that might arise in Queensland and New South Wales.

\section{Exceptions and Limitations to Confidentiality under Specific Legislation}

The following is an overview of the main statutory exceptions to confidentiality in court-ordered mediations, but it will be immediately apparent that the exceptions are not uniform:

1. Consent: Most legislative schemes provide for waiver of confidentiality with 'consent' but there is no consistency as to whose consent is required. In Queensland and Victoria, the consent of all the parties to the mediation is required. ${ }^{121}$ This may be contrasted with section 31(a) of the Civil Procedure Act 2005 (NSW) which provides that a mediator may disclose the information 'with the consent of the person from whom the information was obtained'. ${ }^{122}$

2. Disclosure when required by law: In Queensland it is a reasonable excuse for a mediator "to disclose information if the disclosure is made ... under a requirement imposed under an Act'; ${ }^{123}$ and in New South Wales a mediator may disclose information revealed in mediation 'in accordance with a requirement imposed by or under a law of the State (other than a requirement imposed by a subpoena or other compulsory process) or the Commonwealth'. ${ }^{124}$ No further details or examples are provided. Section 24A of the Supreme Court Act 1986 (Vic) does not contain a similar provision.

3. Enforcing and/or challenging the validity of an MSA: When it comes to proceedings to enforce or to challenge the validity of an MSA in court, the concepts of confidentiality and privilege converge to a significant extent. To avoid repetition, these exceptions are dealt with under the topic of privilege in Part IV.

4. Offence or fraud occurring during the mediation: There is considerable overlap in the concepts of confidentiality and privilege in the case of exceptions for an offence or fraud occurring during the mediation. These exceptions are discussed further under the topic of privilege.

5. Danger to person or property: The New South Wales legislation provides that the mediator may disclose information if there are reasonable grounds to believe that the disclosure is necessary to prevent or minimise

119 Forsyth v Sinclair [No 2] (2010) 28 VR 365 discussed below n 180.

120 Silver Fox (2004) 214 ALR 621. Note however the decision in Simply Irresistible Pty Ltd v Couper [2010] VSC 505, see below n 153.

121 Civil Proceedings Act 2011 (Qld) s 54(2)(a); Supreme Court Act 1986 (Vic) s 24A.

122 See Civil Procedure Act 2005 (NSW) s 31(a).

123 Civil Proceedings Act 2011 (Qld) s 54(2)(f).

124 Civil Procedure Act 2005 (NSW) s 31(e). 
the danger of injury to any person or damage to any property'. ${ }^{125}$ There is no equivalent provision in the Queensland or Victorian legislation.

In none of the schemes discussed here does the legislation make it clear as to whom a mediator may disclose mediation communications. In some cases, such as in proceedings to enforce or challenge the validity of an MSA, it is obvious that disclosure will be made in court. It is not so clear in the case of an offence or fraud occurring during mediation or when a person or property is at risk - presumably disclosure should be made to persons who might be in danger or to relevant authorities such as law enforcement agencies.

In New South Wales and Victoria, regard must be had to the provisions of section 131 of the UEA which were discussed under Part IIIB(1). However, since the UEA is general legislation, it will give way to these specific legislative provisions in the case of conflict.

For the reasons discussed earlier, the common law limitations on the principle of confidentiality (and that of privilege) discussed by the court in AWA Ltd v Daniels ${ }^{126}$ and Williamson $v$ Schmidt ${ }^{127}$ still apply in all jurisdictions discussed in this article. There is no inconsistency between the common law principles articulated in these cases and relevant legislation.

In the next part of the article, the focus is on the without prejudice privilege.

\section{PRIVILEGE AND (IN)ADMISSIBILITY OF MEDIATION COMMUNICATIONS INTO EVIDENCE}

As a general rule, evidence of communications made by a party in a genuine attempt to resolve a dispute cannot be adduced in subsequent litigation. Such communications are protected by the without prejudice privilege. The public policy rationale for this principle is, as with the principle of confidentiality, to encourage parties to be candid with each other with a view to settling disputes without the need for litigation. ${ }^{128}$ However, there are exceptions to the without

125 Ibid s 31(c). In some instances, mediators may be obliged to report to the police or other relevant authority knowledge that 'another person' has committed a serious indictable offence (note that this concerns past offences). However, it is a reasonable excuse for mediators (and legal practitioners) not to report the matter to the police if the knowledge 'was obtained in the course of practising or following' their profession: see Crimes Act 1900 (NSW) ss 316(1), (4)-(5); Crimes Regulation 2015 (NSW) reg 4. Similar provision is made with respect to knowledge of child abuse offences: see Crimes Act 1900 (NSW) ss 316A(6)-(7); Crimes Regulation 2015 (NSW) reg 4. A different approach is taken in Victoria. See Crimes Act 1958 (Vic) ss 327-30 which essentially provide that, in certain circumstances, disclosure of information relevant to a child sexual abuse offence must be made to a police officer. The information is only admissible in evidence with leave of the court or tribunal or the written consent of the person who made the disclosure: at s 329(2).

126 (1992) 7 ACSR 463.

127 [1998] 2 Qd R 317.

128 For a discussion on the rationale behind the without prejudice privilege, see the joint judgment in Field $v$ Commissioner for Railways (NSW) (1957) 99 CLR 285, 291-2 (Dixon CJ, Webb, Kitto and Taylor JJ) ('Field'). See also Silver Fox (2004) 214 ALR 621 on competing policy arguments behind the privilege granted by $U E A$ section 131 and the exception recognised in $U E A$ section 131(2)(h). See generally the discussion by National Alternative Dispute Resolution Advisory Council, Maintaining and Enhancing the 
prejudice principle ie, instances in which evidence of the communications may be admitted in court. The exceptions reflect a competing public interest concern, namely that courts should be appraised of all matters relevant to determination of disputes, or more broadly, to have at their disposal all the information and evidence necessary to do justice in the matter before the court. ${ }^{129}$ The regulatory framework underpinning the without prejudice privilege is discussed below, beginning with the position at common law.

In relation to this principle, no distinction is made between communications that take place in joint and separate sessions in mediation. However, the principle is wide enough to cover all statements made in mediation.

\section{A Regulation of the Without Prejudice Privilege under the Common Law and Contract}

\section{The Position under the Common Law}

According to early formulations of the common law without prejudice privilege, there were two essential pre-requisites or elements for the operation of the privilege, namely: 1) the making of an admission, express or implied, by a party to a dispute and 2) such admission to be made in the course of negotiations to avoid or settle litigation. ${ }^{130}$ This last element was fleshed out more by the court in Field v Commissioner for Railways (NSW) ('Field') ${ }^{131}$ with the court stating that the communication in question must be 'reasonably incidental to the negotiations' ${ }^{132}$ In more recent years, there has been movement away from the strict requirement of the need for an admission. In Lukies $v$ Ripley [No 2] ${ }^{133}$ Young J expressed the view that the 'true rule' is as follows:

If parties have attempted to settle the whole or part of litigation and if they have agreed between themselves expressly or impliedly that they will not give in evidence any communication made during those discussions, then public policy makes those discussions privileged from disclosure in a court of law or equity. ${ }^{134}$

Integrity of ADR Processes Report (n 9) 59-61 [4.4.2]. See also Dewdney (n 11) 19; Arthur (n 1) 91-2; Limbury (n 56) 915-6; Harman, 'Mediation Confidentiality: Origins, Application and Exceptions and Practice Implications' (n 41) 109-10, 117-20 (particularly in the context of family violence issues). As pointed out in Silver Fox (2004) 214 ALR 621, 623-4 [36] (Mansfield J), while the public policy behind section 131(1) of the $U E A$ is to encourage honesty and candour with a view to settling disputes, it is also in the public interest to ensure that 'negotiations should be conducted genuinely and realistically'. See also Hurworth Nominees Pty Ltd v ANZ Banking Group Ltd [2006] NSWSC 1278, [33]-[34] (Bergin J) discussed below n 185. More recently see the decision of Ginnane J in Humphreys $v$ Humphreys [2016] VSC 637, [57], [63] discussed below n 189.

129 Limbury (n 56) 927-8; Lipps (n 1) 56; Firestone and Press (n 5) 13; AKC Koo, 'Confidentiality of Mediation Communications' (2011) 30(2) Civil Justice Quarterly 192, 199-200. The courts are also concerned with developing a regulatory framework which cannot be used to conceal harm and improper behaviour: Firestone and Press (n 5) 13. See also Dewdney who discusses some of the possible disadvantages of too much protection of mediation communications: Dewdney (n 11) 20-1.

130 See the joint judgment in Field (1957) 99 CLR 285, 291-3 (Dixon CJ, Webb, Kitto and Taylor JJ). See also the discussion by Williams JA in Glengallan Investments Pty Ltd v Andersen [2002] 1 Qd R 233, 249 [28].

131 (1957) 99 CLR 285.

132 Ibid 293 (Dixon CJ, Webb, Kitto and Taylor JJ).

133 (1994) 35 NSWLR 283.

134 Ibid 287. 
If this wider view is adopted, there need not be an express or implied admission by a party to the negotiations in order for communications to attract the protection of the privilege. The communications must, however, connect with the merits of the case and not be extraneous to the subject matter of negotiations. ${ }^{135}$

\section{(a) Exceptions and Limitations to the Without Prejudice Privilege under the Common Law}

There are exceptions to the common law without prejudice privilege, such that evidence of what is said or done in mediation may be admissible in later judicial proceedings. As discussed in relation to the principle of confidentiality, evidence may be admitted in circumstances such as the following: ${ }^{136}$

1. Waiver or consent: The parties can agree to waive the protection of privilege since it is a privilege which is for their protection. The consent of the mediator is not required. ${ }^{137}$

2. Enforcing and/or challenging the validity of an MSA: Evidence from settlement negotiations may be admissible to prove that an agreement was reached and to establish its terms, ${ }^{138}$ and in order to challenge the validity of an agreement on the basis of misconduct by a mediation participant. ${ }^{139}$

3. Unlawful conduct: Evidence may be admitted where a party is seeking to rely on the privilege to escape liability for unlawful conduct such as an alleged offence or fraud. ${ }^{140}$ According to the National Alternative Dispute Resolution Advisory Council ('NADRAC'), '[i]t is generally thought that the privilege applies only to civil proceedings and does not extend to

135 Koo (n 129) 199.

136 See Field (1957) 99 CLR 285, 291-3 (Dixon CJ, Webb, Kitto and Taylor JJ); National Alternative Dispute Resolution Advisory Council, Maintaining and Enhancing the Integrity of ADR Processes Report (n 9) 58-61 [4.2]; Arthur (n 1) 92. For a more complete list of exceptions to the without prejudice privilege, see Limbury (n 56) 918-19 where the author also discusses exceptions as they stood in 1999 in England and Wales; Boulle (n 6) 675-8. See also Koo (n 129) 195-9; Bartlet (n 6) 118 for discussion of exceptions to confidentiality recognised under the common law in England. A well-known list of exceptions is articulated by Walker LJ in Unilever plc v Procter \& Gamble Co [2000] 1 WLR 2436, 2444-5.

137 Farm Assist [2009] EWHC 1102 (TCC), [22], [44] (Ramsey J); Koo (n 129) 195.

138 See, eg, Unilever plc v Proctor \& Gamble Co [2000] 1 WLR 2436, 2444-5 (Walker LJ) and Brown v Rice [2007] EWHC 625 (Ch), [56] (Isaacs (QC)) discussed by Limbury (n 56) 916, 918; Koo (n 129) 195-6. In Brown v Rice [2007] EWHC 625 (Ch), the issue was whether (or not) the parties had reached an agreement in mediation. The Court admitted into evidence the mediator's notes, mediator correspondence to the parties, and evidence of what the parties said and did at the mediation. See also Hurworth Nominees Pty Ltd v ANZ Banking Group Ltd [2006] NSWSC 1278, [47]-[48] (Bergin J) which concerned an application for an order for rectification of a Deed entered into following a mediation conducted under the Farm Debt Mediation Act 1994 (NSW), discussed below n 185.

139 Koo (n 129) 195-7; Farm Assist [2009] EWHC 1102 (TCC) in which the claimant sought to have a purported MSA set aside on the basis of economic duress.

140 National Alternative Dispute Resolution Advisory Council, Maintaining and Enhancing the Integrity of ADR Processes Report (n 9) 61 [4.2.2]; Koo (n 129) 197. 
criminal conduct', ${ }^{141}$ nor to breaches of certain legislation such as Australian Consumer Law. ${ }^{142}$

4. Determination of costs of proceedings: Evidence may be admitted to prove factors relevant to the determination of costs of the proceedings (a matter which will be addressed in more detail further below). ${ }^{143}$

Additionally, as with the principle of confidentiality, the courts have held that the without prejudice privilege 'is not concerned with objective facts which may be ascertained during the course of negotiations. These may be proved by direct evidence' ${ }^{144}$ without relying on communications made at mediation.

In the next section, relevant provisions of the standard agreements to mediate issued by the RI and by the Law Society of New South Wales are examined.

\section{Provisions for Without Prejudice Privilege in Sample Agreements to Mediate}

\section{(a) General Provisions as to the Without Prejudice Privilege}

Clause 21 of the RI agreement to mediate provides that, subject to clause 24 which deals with enforcement proceedings, a range of information will be 'kept confidential and will be privileged' and will not be disclosed by the parties or the mediator in any judicial proceedings. ${ }^{145}$ The information thus protected includes 'any settlement proposal'; 'the willingness of a Party to consider any such proposal'; 'any statement, admission or concession made by a Party'; and 'any statement or document made by the Mediator'. ${ }^{146}$ This provision clarifies and enlarges the potentially strict interpretation of the without prejudice privilege at common law, in at least three respects: it protects any statement made during the mediation, not just admissions, concessions and settlement proposals; it protects statements made by the parties and those made by the mediator - none of whom can be compelled to give evidence; and it appears to bind the parties and the mediator in the sense that none of them may seek to compel another mediation participant to give evidence of the specified matters.

Although support persons such as lawyers are not parties to the RI agreement to mediate, the attached acknowledgement and undertaking which must be signed by them, includes similarly worded undertakings not to give or to call evidence. ${ }^{147}$

The clause dealing with privilege in the agreement to mediate issued by the Law Society of New South Wales ${ }^{148}$ is almost identical to the relevant clause in the RI agreement and is broad in the three respects described above. However, there

141 National Alternative Dispute Resolution Advisory Council, Maintaining and Enhancing the Integrity of ADR Processes Report (n 9) 59 [4.2.2].

142 Ibid.

143 Ibid 60 [4.2.2]; Limbury (n 56) 918-19.

144 Field (1957) 99 CLR 285, 291-2 (Dixon CJ, Webb, Kitto and Taylor JJ). See also the judgment of Young J in Lukies v Ripley [No 2] (1994) 35 NSWLR 283, 288-9 where his Honour referred with approval to the judgment of Rolfe J in AWA Ltd v Daniels (Supreme Court of New South Wales, Rolfe J, 18 March 1992) 6.

145 Resolution Institute (n 25) cl 21.

146 Ibid.

147 Ibid $\operatorname{sch} 3 \mathrm{cl} 3$.

148 Law Society of New South Wales (n 79) cl 16. 
are potentially two problems with the Law Society clause which are not present in the RI clause. While the relevant Law Society clause protects 'information prepared for the mediation that is communicated to another party during the mediation', it should be wide enough to also protect the confidentiality of, and privilege attached to, information provided by a party to the mediator. ${ }^{149}$ As mentioned in the discussion dealing with confidentiality under this agreement, the expression 'during the mediation' lacks clarity, leaving some uncertainty as to when 'the mediation' begins and ends.

As for the parties' lawyers, unlike the RI agreement, the confidentiality agreement attached to the 'Agreement to Mediate' issued by the Law Society of New South Wales does not include provisions relating to privilege. This is a significant gap in the documentation.

\section{(b) Exceptions and Limitations to the Without Prejudice Privilege under Agreements to Mediate}

Under the RI agreement, there is only one explicit exception to the without prejudice privilege and that is to be found in clause 24 which was discussed earlier in relation to confidentiality. In some respects, clause 24 is broadly worded. Under this clause, evidence 'of and incidental to the settlement agreement' may be called from the mediator and 'any other person engaged in the Mediation' in proceedings to enforce an MSA. ${ }^{150}$ This provision may be wide enough to allow a party who wishes to resist enforcement of an MSA to call evidence of alleged misconduct by another participant leading up to formation of the MSA.

The provisions of the Law Society agreement to mediate dealing with privilege (as discussed above) are subject to those provisions dealing with enforcement of an MSA. An MSA can be enforced by judicial proceedings, providing the MSA 'is expressed to be binding on all parties'. ${ }^{151}$ By virtue of clause 23, a party may call any other party and the mediator to give 'evidence of the Settlement Agreement'. The relevant provisions of the RI agreement are considerably wider.

Neither the RI agreement to mediate, nor that of the Law Society, clarify whether or not the protection of the privilege can be waived by the parties. However, as the Court in Farm Assist pointed out, the privilege is one that exists between the parties, ${ }^{152}$ and if the parties are in agreement on the issue, they can vary the terms of the agreement to mediate and/or include an appropriate clause in their MSA. No other common law-based exceptions to privilege, such as an exception for an offence or fraud occurring during the mediation, have been stipulated. However as mentioned earlier, some common law principles may continue to apply. The potential for application of the common law is discussed again later.

\footnotetext{
149 Ibid cl 16.4 (emphasis added).

150 Resolution Institute (n 25) cl 24(ii).

151 Law Society of New South Wales (n 79) cl 22.

152 Farm Assist [2009] EWHC 1102 (TCC), [44] (Ramsey J).
} 


\section{B Regulation of the Without Prejudice Privilege under Legislation}

In this part, the legislative framework underlying the without prejudice privilege as it pertains to mediation is examined.

\section{Impact of General Legislation}

If litigation is commenced or continues and a matter proceeds to trial, the issue of privilege afforded mediation communications may be impacted by general legislation. As discussed in Part III, section 131 of the UEA in New South Wales and Victoria is of particular significance. It codifies the common law on the issue. As noted earlier, section 131(1) provides that a communication made in settlement negotiations is not to be adduced in evidence and it is apparent from the decision of the Supreme Court of Victoria in Simply Irresistible Pty Ltd v Couper ${ }^{153}$ that such communications are not admissible in any proceedings, save for in the circumstances provided in section 131(2) by virtue of which communications may be admitted into evidence: ${ }^{154}$ with the consent of 'the persons in dispute' ${ }^{155}$ in proceedings to enforce an MSA or proceedings to challenge the validity of an MSA; ${ }^{156}$ when the communication was made 'in furtherance of the commission of a fraud or an offence or the commission of an act that renders a person liable to a civil penalty'; ${ }^{157}$ and when the communication 'is relevant to determining liability for costs' ${ }^{158}$ On more than one occasion, the courts have held that the terms of section 131(2)(h) override the terms of any confidentiality clause in an agreement to mediate. ${ }^{159}$ In fact, all the clauses in section 131(2) UEA will override, and in some cases fill the gaps in, the terms of a confidentiality or privilege provision in an agreement to mediate. The effect of section 131(2)(h) is that in certain circumstances in New South Wales and Victoria, a court may be appraised of

153 Simply Irresistible Pty Ltd v Couper [2010] VSC 505, [14]-[15] (Kyrou J). In addition to highlighting the narrow aspect of the operation of section 24A of the Supreme Court Act 1986 (Vic), the case demonstrates how broad the operation of section 131 of the $U E A$ may be. The plaintiff, who was a party to an unsuccessful court-ordered mediation, brought separate proceedings against the solicitors who had advised her in the mediation. She alleged negligence on the part of the lawyers (in failing to advise her adequately in relation to an option to an apartment, the subject matter of the proceedings in which mediation was ordered). The plaintiff objected to the introduction of proposed evidence of offers made at the mediation and of her rejection of those offers on the basis of section 24A of the Supreme Court Act 1986 (Vic) and section 131(1) of the UEA. The Court agreed with the defendant solicitors that the effect of section $24 \mathrm{~A}$ is to prohibit the admission of evidence of the mediation at the hearing of the proceedings in which the mediation was originally ordered: at [12]. However, the Court agreed with the plaintiff that the proposed evidence was inadmissible under section 131(1) of the $U E A$ albeit that these were separate proceedings against her former lawyers - section 131(1) provides a blanket prohibition on the introduction of evidence of communications made at mediation. The Court ultimately held that section 131(2)(g) applied and that the proposed evidence should be admitted for the inability of the defendant solicitors to adduce evidence to contradict or qualify the plaintiff's evidence would be likely to mislead the court on the issues of contributory negligence and mitigation by the plaintiff. The evidence was allowed: at [20], [24].

154 This is not a complete list of the circumstances mentioned in UEA s 131.

$155 U E A$ s 131(2)(a).

156 Ibid 131(2)(f).

157 Ibid s 131(2)(j).

158 Ibid s 131(2)(h).

159 Silver Fox (2004) 214 ALR 621, 623-4 [35]-[37] (Mansfield J). 
offers to settle and refusals to accept offers made in mediation for the limited purpose of taking this information into account in determining liability for costs of the proceedings. If a party refuses to accept what turns out to be a reasonable offer to settle, the courts may penalise that party with an adverse costs order. ${ }^{160}$

Where a dispute is referred to mediation by the court, it is necessary to consider the interaction of general legislation such as the UEA and the specific legislation pursuant to which the referral order is made. The examination below reveals, for example, that the operation of section 131(2)(h) of the UEA (and other exceptions to the without prejudice privilege contained in section 131(2)) is affected by specific legislation in both New South Wales and Victoria.

\section{Specific Legislation Governing the Without Prejudice Privilege in Court- Referred Mediations in Queensland, New South Wales and Victoria}

Section 53(1) of the Civil Proceedings Act 2011 (Qld) provides that '[e]vidence of anything done or said, or an admission made, at an ADR process about the dispute is admissible at the trial of the dispute or in another civil proceeding before the court or elsewhere only if all parties to the dispute agree'. ${ }^{161}$ The section clarifies and opens up the potentially narrow common law principle of without prejudice privilege in four respects:

1. The privilege is not limited to admissions made for the purpose of settlement but protects anything done or said at court-ordered mediation as long as it pertains to the dispute.

2. The privilege is not limited to statements made by the parties. It also protects mediator communications, as well as communications made by support persons including legal advisers. None of these mediation participants may be compelled to give evidence.

3. It binds all mediation participants: mediators, parties, legal representatives and anyone else at the mediation are prevented from calling evidence of mediation communications in court.

4. Not only are mediation participants prevented from calling evidence of communications at the trial of the dispute in relation to which the mediation was ordered - they cannot adduce evidence of mediation communications 'in another civil proceeding before the court or elsewhere'. ${ }^{162}$

160 As pointed out in Silver Fox (2004) 214 ALR 621, while the public policy behind UEA section 131(1) is to encourage honesty and candour with a view to settling disputes, it is also in the public interest to ensure that 'negotiations should be conducted genuinely and realistically': at 624 [36] (Mansfield J).

161 Civil Proceedings Act 2011 (Qld) s 53(1). By definition, the legislation only applies to mediation conducted under the UCPR 1999 (Qld): at s 39.

162 Civil Proceedings Act 2011 (Qld) s 53(1) (emphasis added). 
Like its Queensland counterpart, the Civil Procedure Act 2005 (NSW) potentially provides wider scope to the privilege than at common law. ${ }^{163}$ Section 30(4) provides that:

Subject to section 29 (2)-

(a) evidence of anything said or of any admission made in a mediation session is not admissible in any proceedings before any court or other body, and

(b) a document prepared for the purposes of, or in the course of, or as a result of, a mediation session, or any copy of such a document, is not admissible in evidence in any proceedings before any court or other body.

Section 30(4) of the Civil Procedure Act 2005 (NSW) has the following effect:

1. The privilege is not limited to admissions but extends to 'anything said ... in a mediation session'. ${ }^{164}$ For the purpose of this section, 'mediation session' is defined widely to include pre- and post- mediation activities. ${ }^{165}$ The protection extends to documents. The Queensland provision may also extend to documents but section 30(4) removes any doubt that heads of agreement and a signed MSA are protected and inadmissible unless they fall within an exception to the rule.

2. The provision protects statements made by all persons at the mediation. Neither a mediator, a party nor any other participant may be compelled to give evidence of information falling within the ambit of the clause.

3. It appears to bind all participants - neither a mediator, a party nor any other participant can call evidence of communications made at the mediation.

4. Importantly, like the Queensland provision (but unlike section 24A of the Supreme Court Act 1986 (Vic)), things said and done in mediation are not admissible 'in any proceedings before any court or other body'.

As noted above in connection with confidentiality, section 24A of the Supreme Court Act 1986 (Vic) provides that in court-referred mediations 'unless all the parties who attend the mediation otherwise agree in writing, no evidence shall be admitted at the hearing of the proceeding of anything said or done by any person at the mediation'. ${ }^{166}$ Like the other statutory provisions examined above, this section extends the protection of privilege to all communications (not just admissions and concessions) made in mediation. It also provides that no mediation participant may be compelled to give evidence and that no mediation participant

163 It is the only statutory scheme examined here which protects mediation participants from defamation proceedings for things said or done at a mediation session, or in a document sent to or produced to a mediator for the purpose of arrangement of mediation. See Civil Procedure Act 2005 (NSW) s 30(2).

164 Ibid s 30(4)(a).

165 Ibid s 30(1). There does not seem to be a reason for adopting an expansive definition of 'mediation session' for the purpose of privilege, but not for the purpose of confidentiality.

166 Supreme Court Act 1986 (Vic) s 24A (emphasis added). See Magistrates' Court Act 1989 (Vic) section 108(2) and County Court Act 1958 (Vic) section 47B which are in the same terms as section 24A of the Supreme Court Act 1986 (Vic). The wording of the relevant provision in the Magistrates' Court General Civil Procedure Rules 2010 (Vic) rule 50.11 and County Court Civil Procedure Rules 2018 (Vic) rule $50.07(7)$ is slightly different from section $24 \mathrm{~A}$ with the omission of the words 'at the hearing of the proceeding'. 
may call evidence. However, unlike the case with the legislation in Queensland and New South Wales, the protection afforded by section 24A is narrow given that it only prevents the admission of evidence of mediation communications at the hearing of the proceeding in which the mediation was ordered.

\section{Exceptions and Limitations to the Without Prejudice Privilege in the Case of Specific Legislation}

There are exceptions to the privilege created by specific legislation. However, as was the case with the principle of confidentiality, they are not always uniform, nor comprehensive. They include:

1. Consent: In all jurisdictions under consideration, the privilege can be waived with the consent of all the parties to the dispute (or with the written agreement of all the parties who attend the mediation). ${ }^{167}$

2. Enforcing and/or challenging the validity of an MSA: In Queensland, under the terms of section 50(1) of the Civil Proceedings Act 2011 (Qld), a court may, on the application of a party, make an order 'giving effect to an agreement reached at or after a mediation'. However there is no explicit exception to confidentiality and privilege which would allow a party to call evidence from mediation participants to prove that an agreement was reached (should this be in doubt) to establish its terms (should they be in dispute) ${ }^{168}$ or to challenge the validity of an MSA on the basis of, eg, coercion. ${ }^{169}$ In this respect, the terms of the legislation in New South Wales and Victoria are preferable. Section 29(1) of the Civil Procedure Act 2005 (NSW) provides that the court 'may make orders to give effect to any agreement or arrangement arising out of a mediation session' and in those proceedings, by virtue of section 29(2), 'any party may call evidence, including evidence from the mediator and any other person engaged in the mediation, as to the fact that an agreement or arrangement has been reached and as to the substance of the agreement or arrangement ${ }^{\prime} .{ }^{170} \mathrm{In}$

167 Civil Proceedings Act 2011 (Qld) s 53(1); Civil Procedure Act 2005 (NSW) s 30(5)(a) (disclosure may also be made with agreement of all the parties mentioned in a particular document); Supreme Court Act 1986 (Vic) s 24A.

168 See Civil Proceedings Act 2011 (Q1d) ss 48-50. Although this decision is not binding on Queensland Courts, see the case of Al-Hakim v Monash University [1999] VSC 511 where, in relation to a mediation which took place in VCAT, the Victorian Supreme Court admitted evidence of the fact that a settlement had been reached and as to the terms of that settlement. This decision is discussed further below $\mathrm{n} 184$. However, see also the court's view expressed in Wentworth $v$ Rogers [2004] NSWCA 109 discussed in relation to the position in New South Wales, below n 170.

169 See Civil Proceedings Act 2011 (Qld) s 53.

170 The legislation in New South Wales tries to take on board lessons from Wentworth v Rogers [2004] NSWCA 109, a decision by Hodgson JA (dealing with a Notice of Motion to vacate certain directions made by Hodgson JA regarding procedural steps in an appeal) involving the interpretation of sections $110 \mathrm{~N}(1), 110 \mathrm{P}(4)$ and $110 \mathrm{P}(5)$ of the Supreme Court Act 1970 (NSW), the forerunner to the Civil Procedure Act 2005 (NSW). Section 110N was in almost identical terms to section 29(1) of the Civil Procedure Act 2005 (NSW). It was argued that the terms of section $110 \mathrm{~N}$ implied that documentary evidence of an agreement said to have been reached at mediation should be admitted despite the terms of sections $110 \mathrm{P}(4)$ and $110 \mathrm{P}(5)$ by which privilege was conferred over evidence of anything said or done or any document prepared in the course of a mediation session. The Court held that section 110N was 'not 
Victoria, the UEA 2008 (Vic) section 131(2)(f) provides for the admission of evidence in proceedings to enforce an MSA or proceedings in which the making of such an agreement 'is in issue'. ${ }^{171}$ This last phrase is wide enough to enable a party to adduce evidence to challenge the validity of an MSA. This provision is not in conflict with section 24A of the Supreme Court Act 1984 (Vic), for enforcement proceedings and proceedings to challenge the validity of an MSA are separate proceedings to those in which the mediation may have been ordered.

3. Proceedings founded on an offence or fraud: In Queensland, by virtue of section 53 of the Civil Proceedings Act 2011 (Qld), the protection of privilege does not extend to 'a civil proceeding founded on fraud alleged to be connected with, or to have happened during' the mediation (this works in conjunction with section 54(2)(e) which makes it a reasonable excuse for a mediator to disclose information in proceedings founded on alleged fraud). ${ }^{172}$ Ideally, an exception to privilege should be made to also cover circumstances in which an offence is alleged to have occurred during mediation. As for court-ordered mediations in New South Wales, no exception to the privilege is made in the Civil Procedure Act 2005 (NSW) for fraud or for an offence alleged to have occurred during a mediation. It is unlikely that the offence or fraud exceptions in section 131(2) of the UEA 1995 (NSW) will apply in New South Wales as the weight of judicial opinion is that the terms of the Civil Procedure Act 2005 (NSW) are intended to be comprehensive and that it will rule out reliance on the UEA 1995 (NSW) to fill any gaps. ${ }^{173}$ Section 24A of the Supreme Court Act 1986 (Vic) likewise does not contain a provision with respect to fraud or an offence but in Victoria, reliance may be placed on section 131(2)(j) of the UEA 2008 (Vic) (a provision which, potentially, has a wide application). ${ }^{174}$ As discussed earlier, this section provides an exception to the without prejudice privilege for communications (or documents) made 'in furtherance of the commission of a fraud or an offence or the commission of an act that renders a person liable to a civil penalty'. ${ }^{175}$ Section $24 \mathrm{~A}$ is no bar to use of such communications in proceedings based on an alleged offence or fraud (or in proceedings based on, eg, negligence).

4. To prevent danger to person or damage to property: In New South Wales, the privilege may be lost to enable a mediator and others present at the

sufficient to create an implied exception to the plain words of s $110 \mathrm{P}(5)^{\prime}$ : at [26]. This case might be distinguished on the basis that the document produced as a result of the mediation contemplated the drawing up of a later deed: at [30]. Civil Procedure Act 2005 (NSW) section 29(2) was introduced, and section 30(4) which creates the privilege, was made subject to section 29(2).

171 UEA section 131(2)(f) cannot be relied upon in New South Wales: see the decision of Azzi (2007) 71 NSWLR 140, below nn 178-9 and accompanying text.

172 Civil Proceedings Act 2011 (Qld) ss 36(2), 53, 54(2)(e).

173 See the Court's reasoning process which is evident in the judgement of Azzi (2007) 71 NSWLR 140, below nn 178-9 and accompanying text.

174 See the discussion in Part III(B).

175 UEA s 131(2)(j). 
mediation to give evidence in proceedings commenced following a disclosure made under the Civil Procedure Act 2005 (NSW) section 31(c). ${ }^{176}$ Section 31(c) enables a mediator to reveal relevant information 'if there are reasonable grounds to believe that the disclosure is necessary to prevent or minimise the danger of injury to any person or damage to any property'. ${ }^{177}$

Notably absent from the list of exceptions to the without prejudice privilege in specific state legislation is communications which are relevant to the issue of liability for costs of the proceedings when eg, a person fails to accept what turns out to be a reasonable offer to settle made in mediation. Evidence of such communications is not admissible in Queensland under the Civil Proceedings Act 2011 (Qld) and no provision has been made for admission of such evidence under the Evidence Act 1977 (Qld). Similarly, there is no provision made for the admission of this type of communication in the Civil Procedure Act 2005 (NSW). While there is provision in the UEA (namely section 131(2)(h)) the Court in Azzi (Automobiles) Pty Ltd v Volvo Car Australia Pty Ltd ('Azzi') $)^{178}$ held that the specific provisions of the Civil Procedure Act 2005 (NSW) prevail over the inconsistent general provisions of the UEA. ${ }^{179}$

In Victoria, the courts have held that the terms of section 24A of the Supreme Court Act 1986 (Vic) trump those of the UEA in that state. ${ }^{180}$ This means that section 131(2)(h) of the UEA cannot be relied upon to introduce evidence of offers and proposals for settlement made in mediation to determine liability for costs of

176 Civil Procedure Act 2005 (NSW) s 30(5)(b).

177 Ibid s 31(c).

178 (2007) 71 NSWLR 140. See also the decision of Bergin J in Sharjade Pty Ltd $v$ RAAF (Landings) ExServicemen Charitable Fund Pty Ltd [2008] NSWSC 1347 wherein she relied on the decision of Azzi (2007) 71 NSWLR 140 and opined that, "[i]t seems to me that s 30 of the Civil Procedure Act is a complete prohibition in clear and unambiguous terms. I am of the view that s 131(1) is not applicable in this instance and s 131(2)(h) does not apply to attempts to settle a dispute in a mediation session': at [31]. However, cf Humphreys $v$ Humphreys [2016] VSC 637, discussed below n 189 in relation to a private mediation, that is, one that was not court-ordered.

179 Azzi (2007) 71 NSWLR 140, 145-6 [18], see above n 178 and accompanying text. Brereton J cited with approval the case of Rajski v Tectran Corporation Pty Limited [2003] NSWSC 476 in relation to Part 7B Supreme Court Act 1970 (NSW), before the enactment of the Civil Procedure Act 2005, where Palmer J had expressed concern to avoid satellite litigation: at 146 [19]. In Palmer's view, the general provisions of section 131 of the $U E A$ were not intended to apply to the 'special process of settlement negotiation provided by' court-ordered mediation: Rajski v Tectran Corporation Pty Limited [2003] NSWSC 476, [16]. Brereton J seems to take the same view. It is difficult to reconcile this view with the clear words of section 131(1)(a) of the UEA.

180 Forsyth $v$ Sinclair [No 2] (2010) 28 VR 365. In this case, Court of Appeal Justices Neave, Redlich and Acting Justice of Appeal Habersberger held, in relation to court-referred mediations, that the general provision of the 'relevant to costs' exception to section 131 contained in section 131(2)(h) is trumped by the specific provisions of section 24A of the Supreme Court Act 1986 (Vic) which provided that anything said or done at a court ordered mediation may not be adduced in evidence: at 638 [12], 639 [14]. In this case, the respondent sought an adverse costs order against the appellant in an appeal in which mediation had earlier been ordered by the court. See also Pinot Nominees Pty Ltd v Commissioner of Taxation (2009) 181 FCR 392, 397 [30] on the similarly worded section 53B of the Federal Court of Australia Act 1976 (Cth). His Honour Judge Siopis reconciled section 53B and section 131 of the UEA, holding offers of compromise made during the mediation to be inadmissible despite section 131(2)(h) of the UEA (Cth), on the basis that the later did not apply to mediations ordered by the Court under section 53B. 
proceedings. This type of information is only relevant in the very proceedings in which the mediation was ordered, triggering the operation of section 24A.

As such, parties in court-ordered mediations in Queensland, New South Wales and Victoria must find other ways of getting this information before the court where settlement is not reached and the matter proceeds to a trial. The court in Forsyth $v$ Sinclair [No 2] ${ }^{181}$ suggested that, if a party wishes to rely on offers made at mediation, they should make a formal offer using the rules of court ${ }^{182}$ or make a 'Calderbank' offer ${ }^{183}$ outside of and unconnected to the mediation.

The final words in this analysis concern the application of the common law, the operation of which is not necessarily excluded. The courts have shown a willingness to interpret legislation (and agreements to mediate) in such a way as to give effect to the rationale and public policy interests underpinning these principles and, in an appropriate case, to admit evidence to determine matters such as: the fact of an agreement being reached at mediation, the terms of an agreement with a view to enforcing it, ${ }^{184}$ evidence aimed at rectification of an MSA, ${ }^{185}$ and

181 (2010) 28 VR 635, discussed above n 180.

182 Ibid 639 [14]. The civil procedure rules in each state provide mechanisms for parties to make, and accept, written offers to settle. See, eg, part 5 of the UCPR 1999 (Qld).

183 "A "Calderbank offer" is a mechanism which emerged in England for the making of an offer of settlement'. It is so named after the case in which it was discussed by the Court of Appeal in Calderbank $v$ Calderbank [1976] Fam 93. 'The offer, which is made by letter, is said to be made "without prejudice, save as to costs"'. While the letter cannot be admitted as evidence at the trial of the dispute, when the trial is at an end and the "court comes to consider the issue of costs, the letter can be used as a ground for arguing that the offeree should pay the offeror's costs "from the date of rejecting the offer if the offeree fared no better than the offer at trial"': Bobette Wolski, 'Reform of the Civil Justice System Two Decades Past: Implications for the Legal Profession and for Law Teachers' (2009) 21(3) Bond Law Review 192. See generally Anthony Lo Surdo, 'What Makes a Calderbank Letter Effective?' (2004) 42(11) Law Society Journal 58.

184 See, eg, Al-Hakim v Monash University [1999] VSC 511 where proceedings which began with complaints by the plaintiff of discrimination under the Equal Opportunity Act 1995 (Vic) were referred to mediation under the Victorian Civil and Administrative Tribunal Act 1998 (Vic) section 88 and ended up with the plaintiff seeking leave to appeal to the Supreme Court from a decision of the Tribunal: at [1]. The plaintiff objected to the Tribunal's decision to allow evidence of an agreement reached at a tribunalordered mediation on the grounds that it fell within a statutory privilege conferred by the Victorian Civil and Administrative Tribunal Act 1998 (Vic) section 92. The Tribunal had power to enforce an agreement arising from mediation (by virtue of section 93 of the legislation) but section 92 did not provide an exception to privilege to enable the Tribunal to admit evidence of the agreement. The Tribunal had allowed such evidence. On appeal, Bergin J found no error had been made by the Tribunal in allowing evidence of the agreement reached at mediation: at [14]. In her Honour's view, evidence of the fact that a settlement has been reached and as to the terms of that settlement was admissible: at [15]. She observed, at [16]:

It would seem to me to be an extraordinary situation if in practice parties who have reached agreement to settle a proceeding at mediation cannot then seek to enforce their agreement, particularly when section 93(1) of the Act specifically provides that if the parties do agree to settle a proceeding at any time, the tribunal may make any orders necessary to give effect to the settlement.

185 See, eg, Hurworth Nominees Pty Ltd v ANZ Banking Group Ltd [2006] NSWSC 1278, where, despite statutory confidentiality provisions, the Court held that evidence of what happened at a 'successful' mediation conducted under the Farm Debt Mediation Act 1994 (NSW) was admissible in support of the plaintiff farmer's application for an order for rectification of the Deed entered into following the mediation. 
evidence challenging the validity of an MSA. ${ }^{186}$ Such an approach does not undermine the policy of protecting mediation communications with a view to encouraging candour in settlement discussions. ${ }^{187}$ While the court's reasoning in allowing evidence of such matters is perfectly understandable to lawyers, it could not be described as accessible to the parties to a dispute.

\section{CONCLUSION}

The regulatory framework underlying the principles of confidentiality and privilege as they apply to mediation communications is a patchwork of common law principles, contractual terms (in private mediations) and legislation and rules of court. As the examination undertaken in this article demonstrates, there is a lack of uniformity and some inconsistencies in the regulation of these matters in and between:

1. Various agreements to mediate;

2. Agreements to mediate and legislation; and

3. Legislative schemes.

In the case of legislation, there are differences between, and within, jurisdictions. Parties (and mediation providers) often have to navigate between different pieces of legislation and court rules. For instance, in Victoria, when a matter is referred to mediation by the Supreme Court, it is necessary to have regard to the Civil Procedure Act 2010 (Vic), the Supreme Court Act 1986 (Vic) and the Supreme Court (General Civil Procedure) Rules 2015 (Vic), as well as general legislation such as the UEA. It is also necessary to refer to case law in order to work out the priority to be given to inconsistent and conflicting provisions, such as in the case of the conflict between the restrictive provisions of the Civil Procedure Act 2005 (NSW) and the broad provisions of section 131 of the UEA. The situation in Queensland is different again - there is no provision akin to section 131 in that state. A self-represented litigant would have difficulty sorting out these tangles. The information given on the court websites would be of little assistance.

There are significant gaps in agreements to mediate. As demonstrated, they are particularly weak when it comes to including and explaining the limitations and exceptions to the principles of confidentiality and the without prejudice privilege and in advising and explaining about the interaction between the common law, the agreement and legislation.

There are also gaps in every legislative scheme discussed in the article. Perhaps the most striking gap in the legislation in Queensland and New South Wales is the lack of regulation of the conduct of the parties and other participants - aside from

186 Courts have held that, despite the clear wording of provisions such as section 30(4) of the Civil Procedure Act 2005 (NSW) which trump the terms of the Evidence Act 1995 (NSW) section 131(2), section 30(4) does not prevent the admission of evidence by agreement of the parties or because a 'party has chosen to engage in conduct which is inconsistent with the maintenance of the privilege': Woollahra Municipal Council v Secure Parking Pty Ltd [No 2] [2015] NSWSC 452, [27] (Ball J).

187 Woollahra Municipal Council v Secure Parking Pty Ltd [No 2] [2015] NSWSC 452, [27] (Ball J). 
mediators - as regards confidentiality. ${ }^{188}$ There is nothing preventing the parties and their lawyers from discussing mediation communications with third parties unless they are bound by an agreement to mediate and general common law principles. In Victoria, while section 24A of the Supreme Court Act 1986 (Vic) attempts to regulate the conduct of all mediation participants, it only prohibits repetition of mediation communications in court. There is nothing preventing the parties, their lawyers and mediators from discussing the mediation with other third parties.

At the present time parties (and potential parties) to mediation do not receive clear, easy-to-understand, accurate and comprehensive explanations about operation of the principles of confidentiality and privilege. It is undoubtedly difficult to explain these principles with the regulatory system in its current state. Imagine trying to explain the following to a party to a private mediation contemplating litigation in New South Wales: 'If your matter proceeds to trial, evidence of offers to settle made at the mediation are admissible in court when it comes to the court determining liability for costs (as section 131(2)(h) of the UEA prevails over confidentiality and without prejudice provisions in an agreement to mediate). ${ }^{189}$ However, if the court refers your matter to mediation before trial, evidence of settlement offers made in mediation will not be admissible on the issue of costs (for the Civil Procedure Act 2005 (NSW) will override the terms of section 131(2)(h) of the UEA). ${ }^{190}$ How could one explain the (lack of) logic behind these schemes?

Given the importance of confidentiality and privilege to mediation, the challenge for law makers is to regulate these concepts in a way that facilitates easy explanation and understanding for all those involved in the mediation process: courts, other mediation institutions and providers, mediators, legal representatives and the parties including those that are self-represented.

188 There is some very general, arguably insufficient, regulation of the conduct of litigants by the imposition of 'overarching' obligations in the Civil Procedure Act 2010 (Vic) ch 2 pt 2.3; in obligations to act in good faith imposed by the Civil Procedure Act 2005 (NSW) s 27; and general undertakings imposed by rules, such the UCPR 1999 (Qld) r 5.

189 See Humphreys $v$ Humphreys [2016] VSC 637, a mediation between three siblings to resolve various claims brought by one of the siblings under part IV of the Administration and Probate Act 1958 (Vic) concerning administration of their deceased father's estate. Two agreements were reached at the mediation. The plaintiff (a brother to the defendant sister) commenced proceedings against his sister seeking rectification of the second agreement, and partial rescission of that agreement, on the basis that he was misled about the effects of the agreements on his entitlements under the father's will. He alleged negligence, promissory estoppel, unilateral mistake and breach of fiduciary duty: at [7] (Ginnane J). The plaintiff sought to introduce evidence of a particular statement made to him at the mediation. This was a private mediation, not one that was court ordered. The Court had to decide if the Evidence Act 2008 (Vic) section 131(1) applied and if so, whether any of the exceptions in section 131(2) applied so that the statement could be admitted into evidence. The case contains a detailed analysis of the various elements of these sections of the Act: at [53]-[75] (Ginnane J). The Court held that section 131(1) applied to the statement so that it was inadmissible unless one of the exceptions applied: at [63] (Ginnane J). Ultimately the Court found that the statement fell within the terms of section 131(2)(i) and was admissible in evidence: at [75] (Ginnane J).

190 I do not suggest that mediators or lawyers should quote legislation to the parties. 
Until reform takes place, ${ }^{191}$ explanation of these concepts will remain difficult. ${ }^{192}$ The examination undertaken in this article has highlighted some of the issues which need to be considered by law makers and mediation providers tasked with undertaking reform. ${ }^{193}$ At the policy level, consideration must be given to the question of what is the appropriate balance between the sometimes competing public interests mentioned earlier in the article: the need to encourage parties to disputes to settle without litigation, the need to ensure parties take the negotiation process seriously, and the need for the court to have access to all relevant information when cases proceed to trial. ${ }^{194}$ Some commentators have expressed two concerns about the legislative position in New South Wales and Victoria namely that:

1. the protection afforded by the principles of confidentiality and without prejudice under specific legislation such as the Civil Procedure Act 2005 (NSW) is now so wide that court-referred mediations have become "evidentiary "black holes", overriding common law exceptions to the without prejudice rule and the provisions of the $U E A ;{ }^{195}$ and

2. as the specific legislation applies only to court-ordered mediations, parties in those mediations might be worse off than those in private mediations. This raises the question of whether, and if so why, the principles should differ for private and court-ordered mediations.

Another broader policy issue, not discussed at length in this article, concerns application of the principles from AWA Ltd $v$ Daniels ${ }^{196}$ and Williamson $v$

191 Reform efforts most likely will continue to be slow, particularly if each jurisdiction only looks to the situation within its own borders. The New South Wales Law Reform Commission, which was tasked with undertaking a review of 'the statutory provisions that provide for mediation and other forms of alternative dispute resolution' in New South Wales, concluded that statutory intervention was not warranted despite stakeholders' concern that the regulatory system was 'patchwork' in nature: New South Wales Law Reform Commission, Dispute Resolution (Report No 146, 25 June 2018) vii, 2 [1.8], 4 [1.17]. Several model provisions were included in the Commission's Consultation Paper, one of which left the court with discretion as to whether or not to admit evidence: New South Wales Law Reform Commission, Dispute Resolution: Model Provisions (Consultation Paper No 18, December 2016). Ultimately the Commission recommended against adoption of the model provisions and against making 'any other changes to the law’: New South Wales Law Reform Commission, Dispute Resolution (Report No 146, 25 June 2018 ) 1. The Commission gave several reasons for its conclusion, most notably, that a generic provision would require a common approach 'to what is mediation', a matter on which there is no consensus and further, that mediation is context-specific: at 3-4 [1.15]-[1.16].

192 Commentators agree that the inconsistencies and lack of certainty 'may harm the integrity of ADR processes, and undermine existing policy directions to have disputes resolved as early as possible and, if practicable, without (or with minimum) recourse to litigation': National Alternative Dispute Resolution Advisory Council, Maintaining and Enhancing the Integrity of ADR Processes Report (n 9) 57 [4.1]; Nolan and O’Brien (n 17) [7].

193 This article has not dealt with all issues, such as the issue of remedies for threatened breach of confidentiality.

194 On competing public interests, see Limbury (n 56) 927; Leimgruber (n 17) 190-1; Koo (n 129) 199-200; Annalisa LH Peterson, 'When Mediation Confidentiality and Substantive Law Clash: An Inquiry Into the Impact of In Re Marriage of Kieturakis On California's Confidentiality Law' (2007) 8(1) Pepperdine Dispute Resolution Law Journal 199, 202-4.

195 Limbury (n 56) 915.

196 (1992) 7 ACSR 463. 
Schmidt. ${ }^{197}$ Some commentators have suggested that lawyers will keep their clients gagged during mediation for fear that they may say something which, though itself confidential, will set the other side on a search for evidence to prove at trial the facts on which the statement is based. ${ }^{198}$ The answer to these questions will have a profound impact when scoping out exceptions to the principles of confidentiality and without prejudice privilege. Other 'smaller' issues include:

1. How is mediation to be defined? The weight of opinion favours a definition that is wide enough to include preliminary meetings and intake sessions, as well as post mediation activities such as finalisation of an MSA.

2. Since confidentiality and privilege are two separate concepts, should not provision be made for each concept? Should these terms be defined and if so, how?

3. Should consideration be given to development of a separate mediation privilege? ${ }^{199}$

4. Who should be bound by obligations of confidentiality? The strongest feature of the RI agreement to mediate is that it imposes an obligation of confidentiality on mediators, the parties, and other participants who sign a confidentiality agreement or undertaking. Why is the same approach not taken in legislation?

5. If it is permissible to disclose mediation communications, to whom should disclosure be made? Should such issues be left to mediator discretion?

6. In what circumstances should mediation communications be admissible in evidence? Should courts be allowed latitude to decide these issues on a case-by-case basis? ${ }^{200}$

197 [1998] 2 Qd R 317.

198 John Woodward, 'Walking the Tightrope: Exploring the Relationship between Confidentiality and Disputant Participation' (2019) 30(1) Australasian Dispute Resolution Journal 23, 28: Woodward reports that some respondents in his study feared that lawyers would misuse information gained in mediation to 'make collateral enquiries to obtain evidence in admissible form'.

199 For discussion of options for reform, see, eg, Limbury (n 56) 926; Koo (n 129) 203; Agapiou and Clark (n 6) 89.

200 Deason argues that a bright-line rule for situations when confidentiality and other policies conflict is not appropriate and that the question should be determined on a case-by-case basis, using 'in camera' methods: Ellen E Deason, 'Enforcing Mediated Settlement Agreements: Contract Law Collides with Confidentiality' (2001) 35(1) UC Davis Law Review 33, 102 (emphasis omitted). A similar proposal which has at its heart, an exercise of judicial discretion to determine on a case-by-case basis whether evidence should be admitted, is suggested by Peterson (n 194) 208. It is acknowledged however that such an approach 'could result in some degree of judicial unpredictability and inconsistency'. The question remains whether the flexibility from a discretionary approach would outweigh some loss of protection of confidentiality 'and the lack of a uniform legal rule'. Peterson is confident that judges, who are used to discretionary approaches, would over time 'use their discretion to shape a discernible rule by identifying some specific factors relevant to each side of the balance'. NADRAC's suggestion was similar in that it recommended that mediation communications be confidential and privileged save with the consent of the parties or leave of the court - an approach which would leave it up to judges to strike the right balance between competing public interests: National Alternative Dispute Resolution Advisory Council, Maintaining and Enhancing the Integrity of ADR Processes Report (n 9) 68-9 [4.7]. See also discussion of proposed solutions by Limbury (n 56) 927-8. 
7. Currently, under some mediation standards of conduct, mediators and/or mediation providers are ultimately responsible for explaining the concepts of confidentiality and privilege to the parties. ${ }^{201}$ What responsibility should fall to legal representatives, assuming the parties are represented?

8. What are the most effective means of regulation of these concepts? Legislation is necessary to effect changes to laws of procedure and evidence. It is also the best way of achieving uniformity between various jurisdictions. Might uniformity be achieved through legislation such as the Uniform Mediation Act in the US? ${ }^{202}$ Some commentators assert that legislation is the best way to achieve needed reform but they 'recognise that it is no easy task'. ${ }^{203}$ Standards of conduct, while currently nonbinding, provide a good vehicle for education and for setting best practice. The most influential standards in Australia are those issued by the National Mediator Accreditation System ('NMAS'). ${ }^{204}$ However, as Wolski has argued, the standards currently fail to address these issues comprehensively and are themselves in need of reform..$^{205}$

Mediation providers do not have to wait for reform to occur. While explanation of these concepts may be difficult, there is much room for improvement. Currently, important work by organisations such as NADRAC has been overlooked. Take, for instance, the explanation given by NADRAC of the principle enunciated by the

201 See, eg, 'Australian National Mediator Standards' (Practice Standards, 1 July 2015) ss 3(4)(c), 3(5), 6(2)(4) under the National Mediator Accreditation System ('NMAS'), and relevant provisions in both sets of Law Council of Australia standards. The NMAS is an industry-based system which relies on voluntary compliance by mediator organisations (known as Recognised Mediator Accreditation Bodies or 'RMABs') that agree to accredit mediators in accordance with stipulated NMAS Standards: see generally Wolski (n 19) 185. Most law societies and bar associations are RMABs, as is the Resolution Institute: see Mediator Standards Board, National Mediator Accreditation System (1 July 2015)

$<$ https://msb.org.au/themes/msb/assets/documents/national-mediator-accreditation-system.pdf $>$.

'Australian National Mediator Standards' (Practice Standards, 1 July 2015) section 3(5) puts an onus on Court or Tribunal members who are mediating pursuant to legislation and there is no written agreement to mediate, to 'record the participants' understanding as to entry into the process and confidentiality'.

However, obligations on mediators to explain confidentiality and privilege vary: see, eg, FLA 1975 (Cth)

s 10K and Family Law (Family Dispute Resolution Practitioners) Regulations 2008 (Cth) reg 28(1)(b)

which are the most onerous and comprehensive. See also discussion of this issue by Tetunic and Firestone (n 10) 61; Bartlet (n 6) 114; Oberman (n 1) 548.

202 In the US, the Uniform Mediation Act ('UMA') was adopted in an attempt to achieve uniformity and to meet the 'prime concern' of 'keeping mediation communications confidential, because of the importance of creating a setting in which parties feel free "to speak with full candor": Uniform Law Commission, The Uniform Mediation Act (Summary) 1. 'The central rule of the UMA is that a mediation communication is confidential, and if privileged, is not subject to discovery or admission into evidence in a formal proceeding': at 1 . See National Conference of Commissioners on Uniform State Laws, 'Uniform Mediation Act' (Draft Uniform Law, 10-17 August 2001) s 4(a). The UMA was approved by the Commission and recommended for enactment in 2001. It has no force or effect unless and until adopted by individual states. For a more detailed discussion on the significance of the UMA, see Foster and Prentice (n 1) 164-5. Australia has no legislation similar to the UMA. See above n 191 for discussion of the New South Wales Law Reform Commission on the issue of legislative intervention in that state.

203 Agapiou and Clark (n 6) 97. See also Constanze Solveigh Wedding, 'Protection of Trade Secrets in Mediation’ (2016) 27(3) Australasian Dispute Resolution Journal 198, 204.

204 See explanation of the NMAS, above $n 201$.

205 Wolski (n 19) 200-3. 
courts in AWA Ltd v Daniels ${ }^{206}$ and Williamson $v$ Schmidt ${ }^{207}$ on the limitation of these principles. ${ }^{208}$ This information, along with some concrete examples using plain English, can be added to agreements to mediate, explanatory videos and promotional literature on provider websites. ${ }^{209}$

While it may not be feasible or desirable to explain all possible exceptions to these principles to the parties, use of phrases such as 'to the extent provided by the law' is not helpful. The examination undertaken in the article reveals some 'recurring' exceptions such as: to prove that an agreement was made and to establish its terms; to challenge the validity of an agreement on certain grounds; and, when an offence or fraud occurs within mediation, to report it to the appropriate authorities. It is suggested that another vital exception should be made in the case of a threat to harm a person or to damage property. ${ }^{210}$ These exceptions at least could be explained to the parties.

Until reform takes place, care must be taken not to oversell these principles. It is not much of an exaggeration to say that, currently, confidentiality in courtreferred matters is basically unregulated, at least as far as the parties' conduct is concerned. This is not the impression that is given on provider websites, as demonstrated by the opening quotations. Much work remains to be done to clarify and explain the status of mediation communications.

206 (1992) 7 ACSR 463.

207 [1998] 2 Qd R 317.

208 National Alternative Dispute Resolution Advisory Council, 'Your Guide to Dispute Resolution' (n 68) 35 [4.5].

209 It is preferable to have this information easily available to the parties before they commit to mediate in private schemes.

210 See NADRAC's list of recommendations on exceptions to confidentiality: National Alternative Dispute Resolution Advisory Council, Maintaining and Enhancing the Integrity of ADR Processes Report (n 9) $51-3[3.8 .3]$. 